\author{
UNIVERSIDADE DE SÃO PAULO \\ FACULDADE DE ZOOTECNIA E ENGENHARIA DE ALIMENTOS
}

GUILHERME AUGUSTO BONELI

GESTÃO ESTRATÉGICA DE PCP EM UMA EMPRESA DE NUTRIÇÃO ANIMAL: PROPOSTA DE REDESENHO BASEADO NA ANÁLISE DE PROCESSOS DE NEGÓCIOS 
GESTÃO ESTRATÉGICA DE PCP EM UMA EMPRESA DE NUTRIÇÃO ANIMAL: PROPOSTA DE REDESENHO BASEADO NA ANÁLISE DE PROCESSOS DE NEGÓCIOS (VERSÃO CORRIGIDA)

Dissertação apresentada à Faculdade de Zootecnia e Engenharia de Alimentos da Universidade de São Paulo, como parte dos requisitos para a obtenção do título de Mestre em Ciências, do Programa de Mestrado Profissional em Gestão e Inovação na Indústria Animal.

Área de Concentração: Gestão e Inovação na Indústria Animal

Orientador: Prof. Dr. Celso da Costa Carrer 
Ficha catalográfica elaborada pelo

Serviço de Biblioteca e Informação, FZEA/USP, com os dados fornecidos pelo(a) autor(a)

B712g Gestão estratégica de PCP em uma empresa de nutrição animal: proposta de redesenho baseado na análise de processos de negócios / Guilherme Augusto Boneli; orientador Celso da Costa Carrer. -- Pirassununga, 2020.

$66 \mathrm{f}$.

Dissertação (Mestrado - Programa de Pós-Graduação em Mestrado Profissional Gestão e Inovação na Indústria Animal) - Faculdade de Zootecnia e Engenharia de Alimentos, Universidade de São Paulo. 


\title{
GESTÃO ESTRATÉGICA DE PCP EM UMA EMPRESA DE NUTRIÇÃO ANIMAL: PROPOSTA DE REDESENHO BASEADO NA ANÁLISE DE PROCESSOS DE NEGÓCIOS
}

\author{
Dissertação apresentada à Faculdade de Zootecnia e \\ Engenharia de Alimentos da Universidade de São \\ Paulo, como parte dos requisitos para a obtenção do \\ título de Mestre em Ciências com ênfase em Gestão e \\ Inovação na Indústria Animal. \\ Área de Concentração: Gestão e Inovação na \\ Indústria Animal
}

\section{Data de aprovação: 23/09/2020}

\section{Banca Examinadora:}

Prof. Dr. Celso da Costa Carrer - FZEA/USP

Presidente da Banca Examinadora/ Orientador

Profa. Dra. Vera Letticie de Azevedo Ruiz - FZEA

Membro interno ao Programa

Dra. Silvia Robles Reis Duarte - ADM/Neovia

Membro externo ao Programa

Dra. Soraia Marques Putrino - ADM/Neovia

Membro externo ao Programa 


\section{DEDICATÓRIA}

Aos meus pais, Wander e Valdineia, por toda a educação, ensinamentos de amor, compaixão e humildade, e por me apoiar em todas as minhas escolhas.

Aos meus irmãos, Gustavo e Nicolas, que são meus companheiros da vida.

Aos meus avós, Roberto e Penha, que são os alicerces da nossa família.

À minha namorada, Lívia, por tudo que você é e representa para mim.

Aos meus sogros, Junior e Paula, que sempre me aconselham em minhas decisões;

aos meus cunhados Thamiris, Arthur, Lucas e Cíntia pelo companheirismo e amizade; e à minha afilhada, Cecília, que nos trouxe muita alegria. 


\section{AGRADECIMENTOS}

À Deus, primeiramente, por sempre me guiar e me conceder saúde para que eu consiga alcançar todos os objetivos almejados.

À minha família, por todo apoio prestado durante esse período, e principalmente pelos ensinamentos e exemplos que me deram.

Em especial, à minha namorada, Lívia Cirelli, por toda a paciência, companheirismo e ajuda durante toda a parte teórica da pesquisa.

Ao meu orientador, Prof. Dr. Celso da Costa Carrer, pelas orientações sucintas e objetivas, e também pela amizade que construímos ao longo destes semestres.

À minha Equipe de Planejamento e Controle da Produção, por me dar todo o apoio na parte prática ao longo do desenvolvimento da pesquisa.

Ao meu Gestor, Leandro Vichiato, por toda confiança e incentivo profissional.

À todos os professores e funcionários do Programa de Pós-Graduação em Gestão e Inovação da Indústria Animal, que partilharam seus conhecimentos.

À Faculdade de Zootecnia e Engenharia de Alimentos - FZEA/USP e ao Programa de PósGraduação em Gestão e Inovação da Indústria Animal pelo apoio.

O presente trabalho foi realizado com o apoio da Coordenação de Aperfeiçoamento de Pessoal de Nível Superior (CAPES). 
"Boa sorte é o que acontece quando a oportunidade encontra o planejamento" Thomas Edison 


\section{RESUMO}

BONELI, G. A. Gestão estratégica de PCP em uma indústria de nutrição animal: proposta de redesenho baseado na análise de processos de negócios, 2020. 66 f. Dissertação (Mestrado em Gestão e Inovação na Indústria Animal) - Faculdade de Zootecnia e Engenharia de Alimentos, Universidade de São Paulo, Pirassununga, 2020.

O ramo da nutrição animal é uma das atividades econômicas que se destaca pela sua presença em todo o território nacional, sendo seu principal objetivo propiciar uma produção com baixo custo, respeitando princípios básicos de bem-estar animal. Para a produção com maior eficácia e eficiência é necessário implantar um programa de melhoria contínua, o qual é caracterizado por um amplo processo concentrado na inovação incremental que envolve toda a organização. O presente trabalho teve como objetivo analisar o processo atual de gestão do Departamento de Planejamento e Controle da Produção (PCP) de uma empresa de nutrição animal, no intuito de melhorar a eficiência por meio de uma proposta de redesenho de suas atividades baseada na análise de processos de negócios. Neste contexto, é importante destacar os resultados obtidos na pesquisa qualitativa, onde analisou-se o impacto do redesenho do PCP no âmbito da empresa, nas mais diferentes facetas: estratégica, organizacional e na integração das ferramentas propostas. Sob o panorama geral, apreendido pela metodologia da pesquisa e obtido através da revisão da literatura e com base nos dados primários colhidos no próprio acervo e recursos humanos da empresa, ressalta-se a relevância e a eficácia da análise de gerenciamento de processos de negócios para legitimar os resultados obtidos qualitativamente. Ao final, pode-se afirmar que o PCP precisa ser o eixo operacional dentro de uma organização e que em paralelo necessita-se ter uma gestão focada para oferecer suporte para que a empresa consiga chegar a níveis satisfatórios na competitividade do mercado.

Palavras-chaves: gestão de estoques; gestão estratégica; planejamento e controle da produção. 


\begin{abstract}
BONELI, G.A. Strategic management of PCP in an animal nutrition industry: redesign proposal based on business process analysis. 2020. 66 f. M.Sc. Dissertation - Faculdade de Zootecnia e Engenharia de Alimentos, Universidade de São Paulo, Pirassununga, 2020.
\end{abstract}

The branch of animal nutrition is one of the economic activities that stands out for its presence throughout the national territory, its main objective being to provide low-cost production, respecting basic principles of animal welfare. For production to be more effective and efficient, it is necessary to implement a continuous improvement program, which is characterized by a broad process focused on incremental innovation that involves the entire organization. This work aimed to analyze the current management process of the Production Planning and Control Department (PCP) of an animal nutrition company, in order to improve efficiency through a proposal to redesign its activities based on the analysis of business processes. In this context, it is important to highlight the results obtained in the qualitative research, where the impact of the redesign of the PCP within the scope of the company was analyzed in the most different facets: strategic, organizational and in the integration of the proposed tools. Under the general panorama, apprehended by the research methodology, obtained through the literature review, and based on the primary data collected from the company's own collection and human resources, the relevance and effectiveness of the analysis of business process management is highlighted to legitimize the results obtained qualitatively. In the end, it can be said that the PCP needs to be the operational axis within an organization and that in parallel it is necessary to have a focused management to offer support so that the company can reach satisfactory levels in the market's competitiveness.

Key words: inventory management; strategic management; planning and production control. 


\section{LISTA DE ILUSTRAÇÕES}

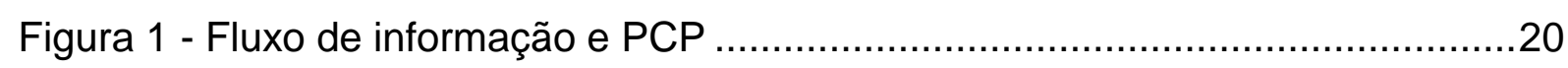

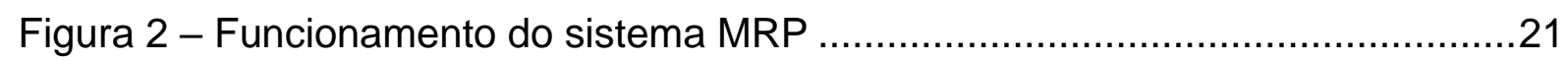

Figura 3 - Alguns motivos para o surgimento dos estoques....................................24

Figura 4 - Gestão de estoques (física e estratégica) ............................................25

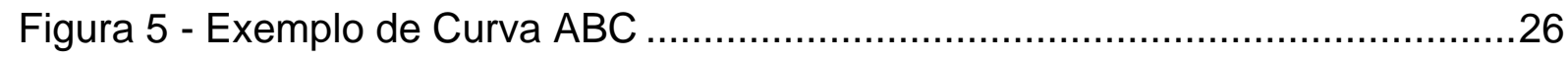

Figura 6 - Elementos principais para a gestão de demanda....................................28

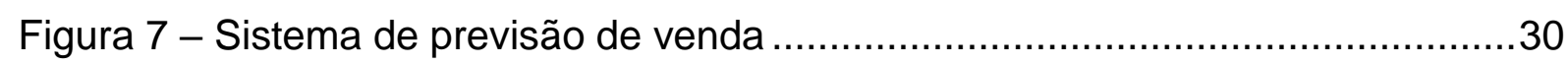

Figura 8 - Fluxograma: Como amarrar os sapatos ................................................... 34

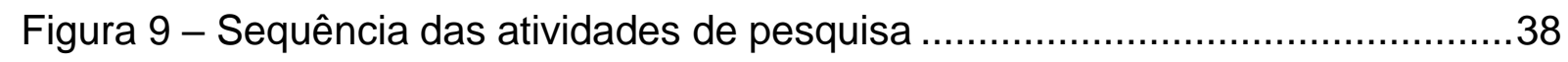

Figura 10 - Matriz de Priorização de Riscos em Processos .....................................39

Figura 11 - Eixo Central da Organização - Gestão Anterior ...................................42

Figura 12 - Redesenho do Eixo Central da Organização - Gestão Atual .................43

Figura 13 - Estrutura Organizacional - Gestão Anterior........................................ 44

Figura 14 - Redesenho da Estrutura Organizacional - Gestão Atual .........................44

Figura 15 - Fluxo de Programação - Gestão Anterior ............................................46

Figura 16 - Matriz de priorização das atividades realizadas pelo PCP .....................49

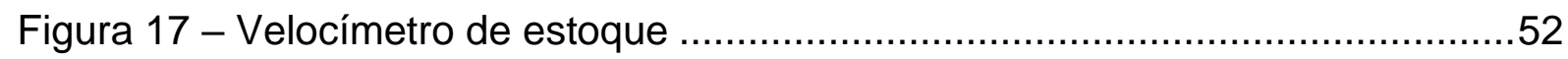

Figura 18 - Redesenho do Fluxograma de Programação - Gestão Atual ...................54

Figura 19 - Primeira etapa do redesenho do fluxograma de programação ................55

Figura 20 - Segunda etapa do redesenho do fluxograma de programação ..............56

Figura 21 - Terceira etapa do redesenho do fluxograma de programação................57

Figura 22 - OTIF da Empresa estudada de novembro de 2018 a abril de 2020 ......57 


\section{LISTA DE QUADROS}

Quadro 1 - Atividades realizadas pelo PCP .47

Quadro 2 - Classificação das atividades realizadas pelo PCP de acordo com seu grau de impacto e probabilidade 48 


\section{LISTA DE SIGLAS E ABREVIATURAS}

$\begin{array}{ll}\text { ABNT } & \text { Associação Brasileira de Normas Técnicas } \\ \text { ABPMP } & \text { Association of Business Process Management Professionals } \\ \text { BPM } & \text { Business Process Management } \\ \text { ERP } & \text { Enterprise Resource Planning } \\ \text { IFAC } & \text { International Federation of Accountants } \\ \text { JIT } & \text { Just in Time } \\ \text { KPI } & \text { Key Performance Indicator } \\ \text { MP } & \text { Matéria Prima } \\ \text { MRP } & \text { Materials Requerements Planning } \\ \text { OTIF } & \text { On Time In Full } \\ \text { PCP } & \text { Planejamento e Controle da Produção } \\ \text { WMS } & \text { Warehouse Management System }\end{array}$




\section{SUMÁRIO}

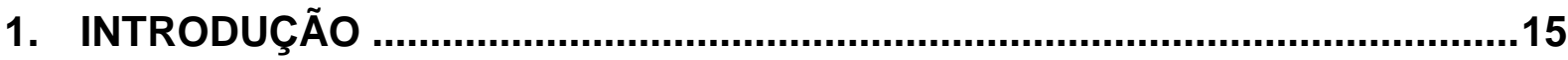

2. OBJETIVOS E HIPÓTESE ........................................................................18

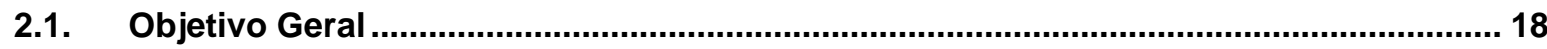

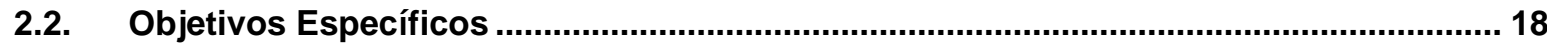

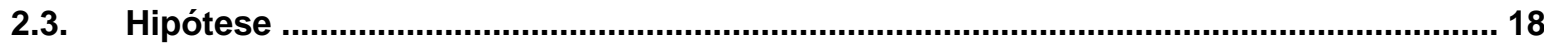

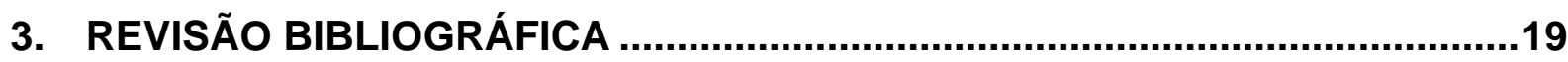

3.1. Planejamento e Controle da Produção (PCP) ….............................................................. 19

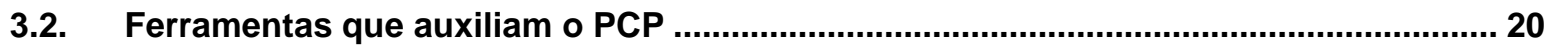

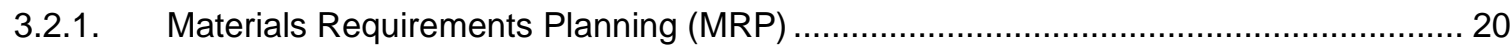

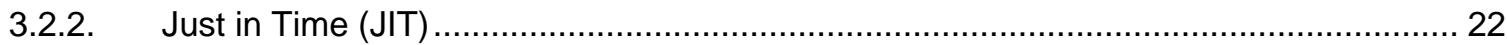

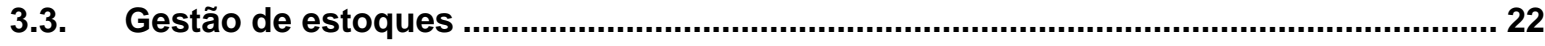

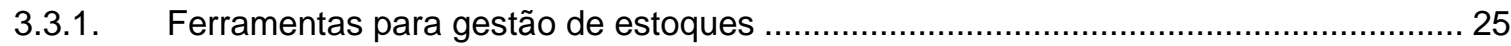

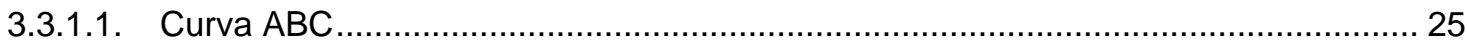

3.3.1.2. Warehouse Management System (WMS) ...................................................... 26

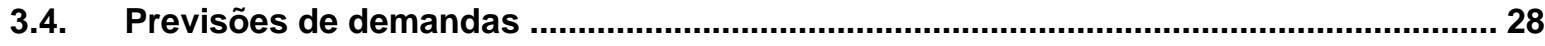

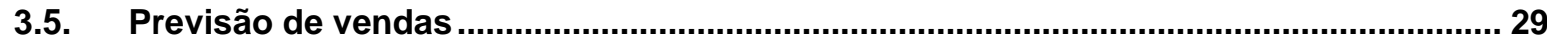

3.6. Ferramenta para previsão de demanda - Enterprise Resource Planning (ERP)........... 30

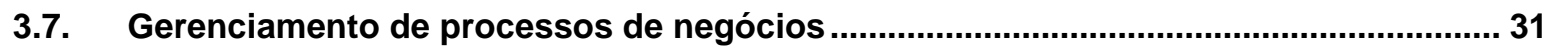

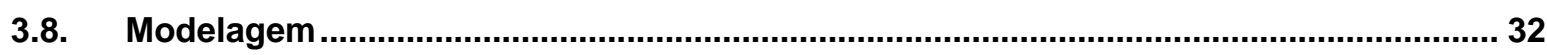

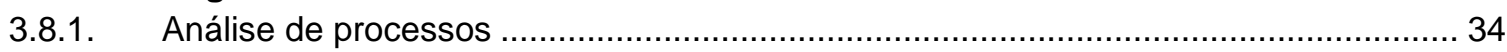

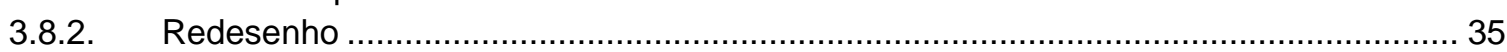

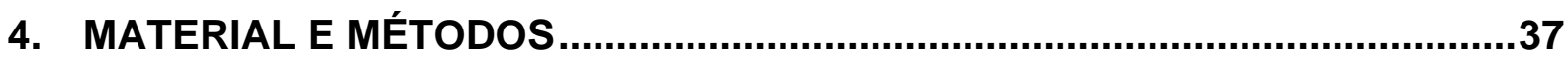

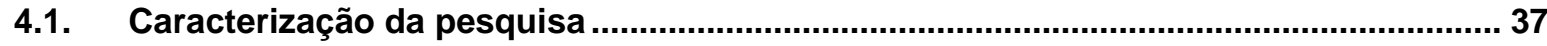

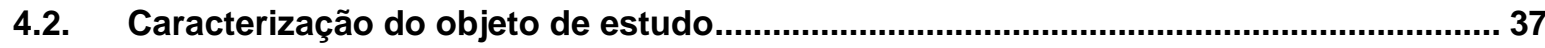

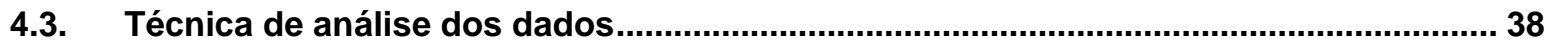

5. RESULTADOS E DISCUSSÃO ................................................................41

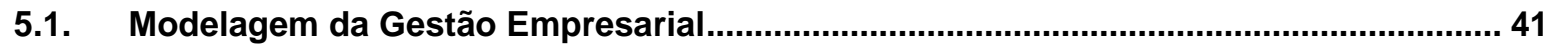

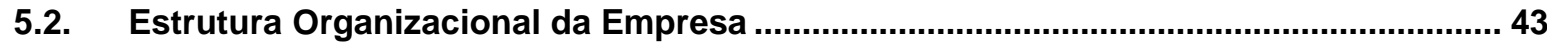

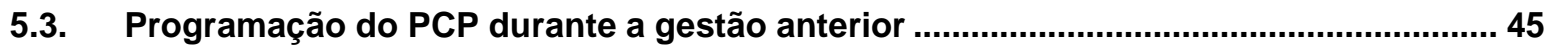

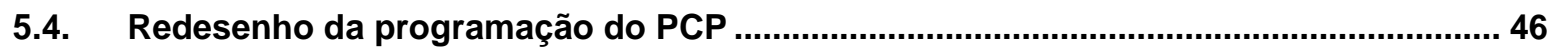

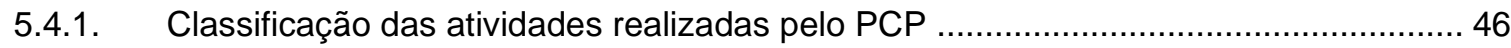

5.4.2. Ferramentas utilizadas pela empresa na gestão anterior ........................................ 50

5.4.3. Ferramentas utilizadas para realizar o redesenho da programação do PCP ............... 51

5.4.4. Redesenho do fluxograma de programação do PCP ............................................... 53

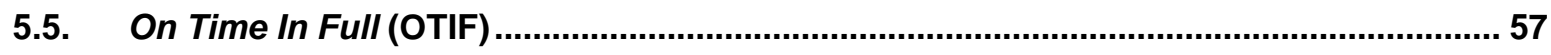

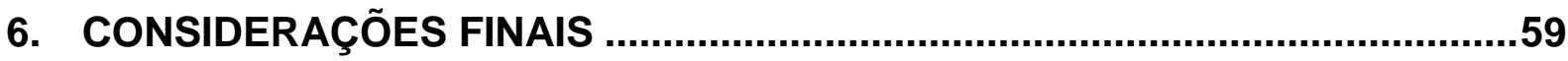

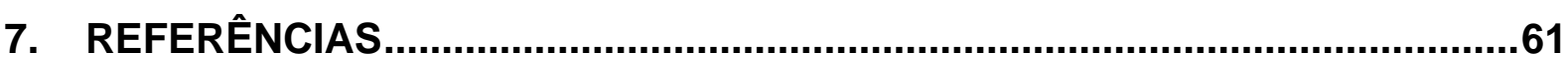




\section{INTRODUÇÃO}

A busca por um diferencial nas organizações tem se intensificado nas últimas décadas, visando a competitividade no mercado, por meio da otimização da produção, venda e distribuição. Neste movimento, deu-se ênfase em ações que estejam abrangendo as características dos fatores internos e externos da organização. Uma empresa é considerada competitiva quando consegue adaptar-se às mudanças tecnológicas, econômicas e sociais, além de outras variáveis externas, tendo a condição de garantir e sustentar resultados superiores aos desenvolvidos pela concorrência (STONEHOUSE; SNOWDON, 2007). Contudo, é possível afirmar que a busca pela produtividade em mercados globais impõe desafios para as organizações e requerem análises periódicas e mudanças de seus processos de fabricação e de obtenção de informações (BEDIN; GASPAROTTO, 2018).

Visto isso, profissionais e empresas buscam com maior empenho desenvolver técnicas e ferramentas que aspiram produzir em maior quantidade, maximizar os lucros e essencialmente minimizar custos (CARINA; ATTADIA; MARTINS, 2003). A expressão "melhoria contínua", que ganha cada vez mais força nos setores de produção e vem se tornando muito popular entre as empresas nos últimos anos, é definida como um amplo processo concentrado na inovação incremental que envolve toda a organização, no qual as prioridades competitivas que envolvem o desenvolvimento dos recursos da produção devem estar alinhadas com os objetivos e as estratégicas corporativas da organização. Por constituir-se num conceito simples, de fácil entendimento e de baixo nível de investimento, a "melhoria contínua" tem se consagrado como uma das formas mais eficientes de aumentar a competitividade de uma empresa (BESSANTE et al., 1994; CAFFYN, 1999; BEDIN; GASPAROTTO, 2018).

O ramo de negócios que envolve a nutrição animal é uma das atividades econômicas que mais se destacaram em termos de crescimento, nas últimas décadas, no agronegócio brasileiro. Ela tem por objetivo a produção de alimentos que atendam os requerimentos nutricionais em cada etapa de vida do indivíduo, buscando sempre o melhor preço, rendimento, qualidade e produtividade (ANDRIGUETTO; PERLY, 1994). 
Os animais, sejam eles para consumo humano ou de estimação, necessitam de uma alimentação balanceada e de qualidade. A nutrição animal reúne os pontos importantes e imprescindíveis para a saúde de várias espécies animais (HÖTZEL, 2014).

A crescente expansão do mercado de produtos para a alimentação de animais de estimação e criação apresenta-se em destaque. $O$ abastecimento de matériaprima, dosagem e formulação dos produtos, moagem, cozimento, secagem e ensaque fazem parte do processo de produção. Todos esses processos estão ligados diretamente na "melhoria contínua" do processo de desenvolvimento dos produtos (ALMEIDA, 2020).

O Departamento de Planejamento e Controle da Produção (PCP) é o eixo operacional de uma organização e trata-se de uma importante e estratégica função gerencial dentro de qualquer processo produtivo (KUMAR; SINHA, 1999). A previsão da demanda, o planejamento e o controle da produção e a gestão dos estoques são atividades essenciais do PCP, visto que é o responsável pelas perguntas "o que produzir", "como produzir" e "quanto produzir". O PCP planeja e executa suas ações no intuito de produzir o produto correto, na quantidade certa, no momento exato para que consiga atender todos os clientes com eficiência e eficácia (GISLON, 2012). A falta desse planejamento pode afetar de modo direto o processo produtivo e logístico, gerando retrabalho, transtornos com atrasos em entregas e falta de estoque de matérias primas, o que compromete a credibilidade da organização perante seus clientes e fornecedores (RAMOS; CÂNDIDO; ESTENDER, 2019).

É importante ressaltar que o PCP se relaciona com todas as funções do sistema de produção e esferas da organização, no qual ele atua nos três níveis hierárquicos: i) estratégico; ii) tático e iii) operacional. No primeiro são determinadas quais as políticas estratégicas da organização, no qual o PCP auxilia no preparo do planejamento estratégico de produção. No nível tático, o PCP constrói o plano mestre de produção, e no nível operacional o PCP é o responsável por programar e controlar a produção, além de gerir os estoques, as ordens de compras e os processos de fabricação e montagem, entre outros processos (UEDA, 2016). 
Diante do exposto, surge a justificativa para o presente trabalho, que trata de um estudo de caso em que a proposta de redesenho de processos vem a comprovar a importância de uma gestão estratégica para o PCP de uma indústria de nutrição animal. Neste sentido, objetiva-se verificar como funciona o planejamento e o controle da produção, além de analisar as demandas de produtos, programar de forma eficiente e eficaz e gerir o estoque de forma com que se tenha apenas o necessário para o momento. Ao final, busca-se propor um redesenho dos processos operacionais para aumentar a eficácia da gestão e a consecução de resultados empresariais. 


\section{OBJETIVOS E HIPÓTESE}

\subsection{Objetivo Geral}

Analisar o processo atual de gestão do Departamento de Planejamento e Controle da Produção (PCP) de uma empresa de nutrição animal, no intuito de melhorar a eficiência por meio de uma proposta de redesenho de suas atividades baseada na análise de processos de negócios.

\subsection{Objetivos Específicos}

a) Avaliar o fluxograma e as ferramentas utilizadas na gestão do Planejamento e Controle da Produção da empresa, assim como evidenciar estratégias que poderão aprimorar o processo;

b) Adaptar metodologias para implantar as ferramentas escolhidas na nova proposta de gestão de PCP;

c) Propor redesenho operacional da gestão por meio de uma análise de processos de negócios.

\subsection{Hipótese}

A hipótese (H1) comprovará a existência de um espaço para a consecução de uma proposta de redesenho, baseado na análise de processos de negócios, a fim de que o Departamento de Planejamento e Controle da Produção (PCP) melhore seu desempenho e seu papel fundamental na gestão estratégica em uma empresa de nutrição animal. 


\section{REVISÃO BIBLIOGRÁFICA}

\subsection{Planejamento e Controle da Produção (PCP)}

O planejamento e controle da produção (PCP) ocupa-se de gerenciar a operação produtiva de modo a satisfazer sempre a demanda dos consumidores. $\mathrm{Ou}$ seja, qualquer atividade produtiva requer planos e requer controle, embora o grau de formalidade e os detalhes possam variar (SLACK; CHAMBERS; JOHNSTON, 2009). É um dos papéis do PCP garantir adequação entre as decisões operacionais e as decisões ou necessidades estratégicas da organização, conectando-se com os demais setores da empresa, com os fornecedores e clientes. Portanto, O PCP representa o elo entre o nível estratégico e os níveis abaixo, suportando a estrutura para traduzir as intenções estratégicas em planos táticos e operacionais concretos (JUNIOR; GODINHO FILHO, 2020)

De acordo com Rodrigues e Inácio (2010), o PCP tem como função a coordenação e o apoio do sistema produtivo. Esse sistema caracteriza-se pelo processo de transformação de entradas (inputs) em saídas (outputs) e está envolvido com diversas áreas ligadas, direta ou indiretamente, com a produção para buscar informações e outros recursos necessários à elaboração e execução dos planos de produção. Desta maneira, um sistema de produção é qualquer coisa que, por meio de processos, transformam um input em output com algum valor agregado (RAMOS, CÂNDIDO e ESTENDER, 2019)

De certo modo, o planejamento e o controle da produção dizem respeito ao que o mercado requer e o que as operações podem fornecer (Figura 1). As atividades de PCP proporcionam os sistemas, procedimentos e decisões que juntam diferentes aspectos da oferta e da demanda. É preciso intermediação entre suprimentos e demanda, o que garantirá que os processos produtivos ocorram de forma eficaz e eficientemente e que produzam os produtos e serviços requeridos pelos clientes, ou seja, o PCP é a junção entre as estratégias da empresa e o sistema produtivo, e se caracteriza pela linha de produção trabalhando de acordo com um cronograma préestabelecido. (DA SILVA; DUARTE; DA SILVA, 2019; MONTOR; BERTACI, 2020; SLACK; CHAMBERS; JOHNSTON, 2009). 
A diferença entre o planejamento e o controle não é clara, nem na teoria e nem na prática, contudo, há algumas características gerais que ajudam a distinguir os dois. Planejamento é a formalização do que se pretende que aconteça em determinado momento no futuro e controle é o processo de lidar com os possíveis imprevistos que possam impactar no planejamento (SLACK; CHAMBERS; JOHNSTON, 2009). Já para Rodrigues e Inácio (2010), esses dois conceitos estão entrelaçados, pois quanto maior a integração entre os diversos setores envolvidos no PCP, maior será o êxito dos resultados atingidos.

Figura 1 - Fluxo de informação e PCP

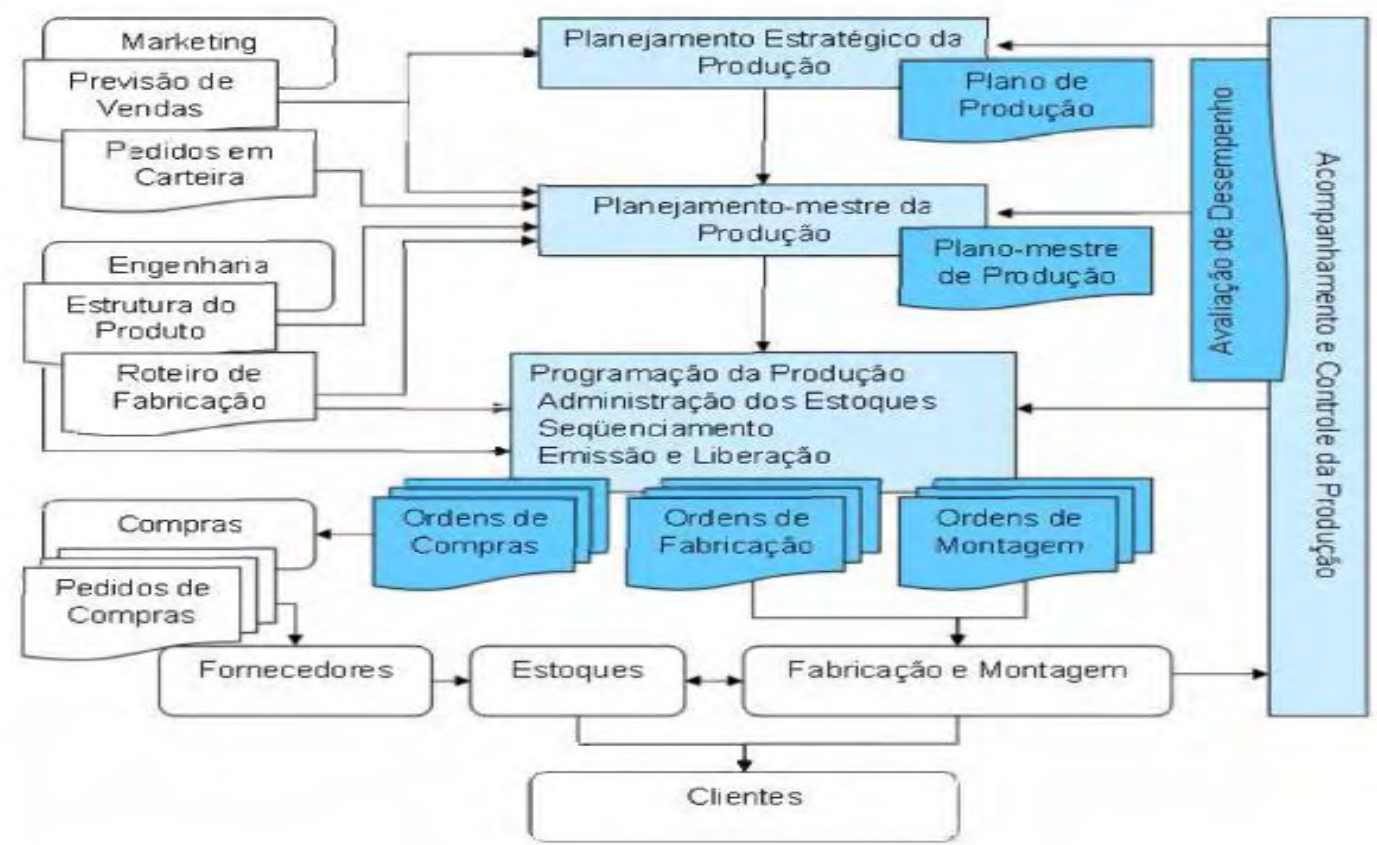

Fonte: TUBINO, D. F. Planejamento e controle da produção: teoria e prática. São Paulo: Atlas, 2009.

\subsection{Ferramentas que auxiliam o PCP}

A seguir são relatadas duas técnicas que visam apoiar as atividades do PCP em uma dada empresa.

\subsubsection{Materials Requirements Planning (MRP)}

O Materials Requirements Planning (MRP) ou planejamento das necessidades de materiais é uma ferramenta importante para a rotina do PCP, pois é ele que auxilia na tomada de decisão e na gestão de compras e estoque. O MRP calcula, 
automaticamente, as necessidades de materiais e os planos de produção de pedidos de vendas previstos ou conhecidos, assim como ajuda a calcular volumes e momentos para suprir demandas do futuro, ou seja, através dessa ferramenta é possível identificar o ponto ideal em que se deve realizar as compras para atender certa demanda e qual momento se deve iniciar a produção para alcançar o melhor volume de estoques (MOREIRA, 2001; SLACK; CHAMBERS; JOHNSTON, 2009).

O MRP (Figura 2) é uma ferramenta para planejar e controlar a produção a partir da demanda original advinda do programa mestre de produção com foco na programação das necessidades de materiais. Ele utiliza a base de dados de software e os interliga com as capacidades de estoque para efetuar uma "explosão" mais conhecida como cálculo das necessidades. De acordo com Bianchini et al. (2017), o MRP é um sistema capaz de fazer previsões de demanda em grande escala, desde que se utilize a base de dados corretamente. A ferramenta é de grande utilidade para o sistema de produção, pois desse modo os níveis de estoque sempre estarão de acordo com a necessidade de produção, não ocasionando paradas na fábrica e, consequentemente, prejuízo financeiro (COSTA; DOS SANTOS GURGEL; DA COSTA SOUZA, 2020).

Figura 2 - Funcionamento do sistema MRP

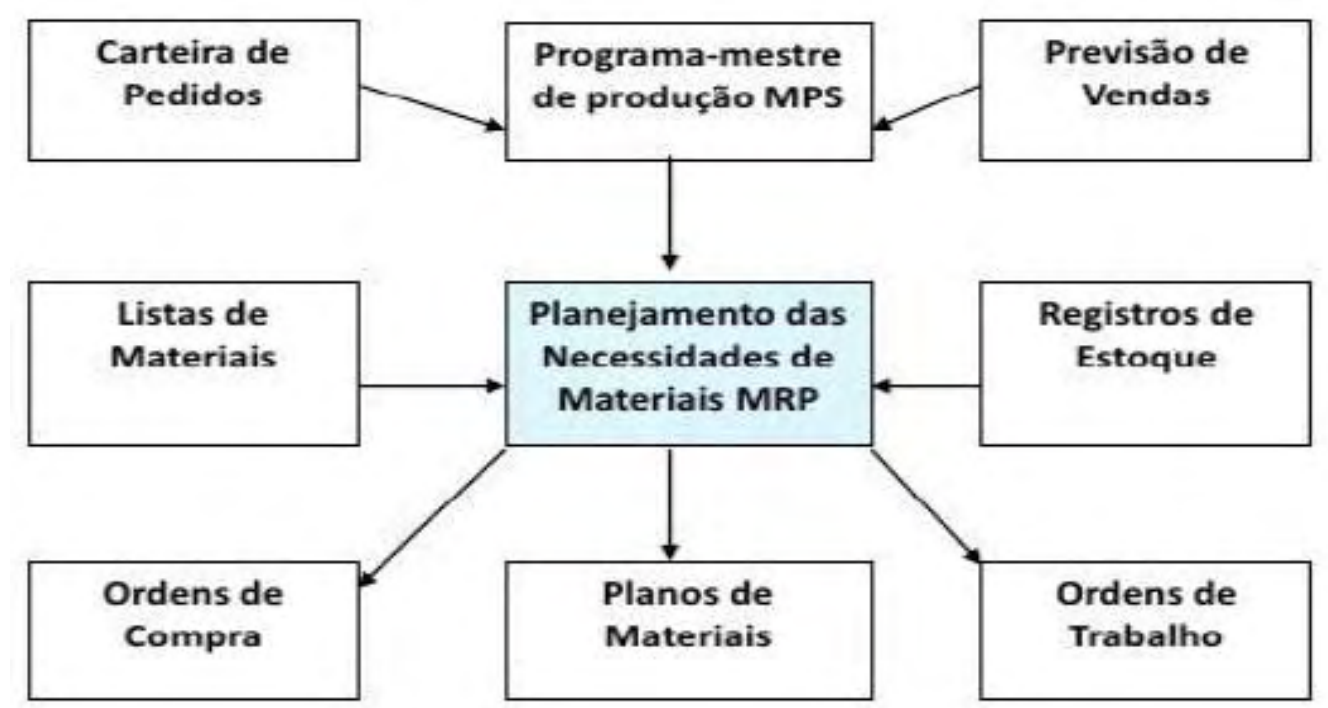

Fonte: SLACK N.; CHAMBERS, S.; JOHNSTON, R. Administração da produção. São Paulo: Atlas, 2009. 


\subsubsection{Just in Time (JIT)}

O Just in Time (JIT) é o conceito mais básico de se produzir bens ou serviços exatamente no momento em que são necessários, ou seja, não se produz antes para não gerar estoques e nem depois para que não se corra o risco de não atender os clientes. O JIT visa atender à demanda com excelente qualidade e sem desperdícios (BESERRA; ESTENDER, 2016).

As principais características dessa técnica são a diminuição de estoques, a eliminação de desperdícios e o método de produção "puxada" (no sentido da demanda), que faz com que se inicie a produção somente a partir de um pedido (CORRÊA; CORRÊA, 2000). Segundo Slack, Chambers e Johnston (2009), o JIT visa simplificar a produção, a fim de deixá-la somente com o essencial para ser usado, significando que todos os elementos que pertencem ao processo de produção serão reduzidos ao máximo e serão entregues no momento exato de necessidade para não ocorrer um excesso e nem uma falta nos estoques.

Apesar de apresentar como vantagens os estoques baixos e as entregas nos momentos ideais, o JIT também pode apresentar desvastagens, por exemplo, quando as matérias primas necessárias para a produção atrasam ou eventuais falhas acontecem na linha de produção, tornando o processo produtivo irregular (CORRÊA; CORRÊA, 2000). Neste sentido, para que a ferramenta consiga funcionar perfeitamente é necessário que ela trabalhe em conjunto com outras, garantindo parcerias com fornecedores, visto que eles serão responsáveis pela entrega do produto.

\subsection{Gestão de estoques}

Estoque é a definição da acumulação armazenada de recursos materiais em um sistema de transformação. O estoque, portanto, é uma reserva tanto de materiais de transformação, quanto de produtos acabados a serem utilizados na continuação do processo e em momentos oportunos. Pode-se dizer, desse modo, que o estoque existirá por que ocorre sempre uma diferença no ritmo entre o fornecimento da matéria prima e da demanda por produtos acabados (VIANA, 2000). 
De acordo com o mesmo autor, os estoques representam recursos ociosos de valor econômico, destinado aos processos de produção e atendimento ao mercado consumidor. Já a gestão, segundo Rigoleto, Pereira e Duran (2017), pode ser definida como um ato de administrar e organizar, de forma a alcançar resultados significativos e metas pré-estabelecidas. Assim, uma gestão de qualidade deve ser baseada nos conhecimentos econômicos de mercado que estudam maneiras de realocar os recursos escassos. A gestão desses recursos deve ser projetada e mantida em níveis ideais, para se buscar sempre o melhor equilíbrio entre estoque e demanda. Neste sentido, Slack, Chambers e Johnston (2009) concordam que, ao se promover o equilíbrio entre a capacidade produtiva e a demanda, pode-se alavancar resultados. Já o equilíbrio incorreto pode ser potencialmente desastroso e resultar no crescimento de custos. Portanto, os níveis de estoque devem ser acompanhados, sistemática e periodicamente, para que problemas sejam evitados.

Os estoques existem para que não ocorra o risco de não atender uma demanda inesperada (Figura 3). Eles existem a fim de que os consumidores sejam sempre e plenamente atendidos, funcionando como uma base amortecedora entre o mercado consumidor e o mercado supridor (VIANA, 2000).

Existem quatro tipos de estoque: estoque de proteção, estoque de ciclo, estoque de antecipação e estoque de canal. O estoque de proteção, também chamado de estoque isolador, existe para compensar as incertezas e variações entre demanda e fornecimento. É, normalmente, usado em organizações que possuem maior dificuldade em prever a demanda. O estoque de ciclo ocorre na produção em que os itens não podem ser processados simultaneamente, havendo a necessidade de produção de lotes mínimos para atender a demanda. Estoque de antecipação é aquele usado quando as variações de demanda são significativas e previsíveis, com demanda sazonal. Já o estoque de canal é todo o estoque em trânsito, desde a saída no fornecedor até a descarga no cliente (SLACK; CHAMBERS; JOHNSTON, 2009). Além desses, segundo Côrrea e Corrêa (2000), ainda existem tipos de estoque em processo, sendo eles: estoques de matérias-primas e componentes comprados, estoques de material em processo, estoque de produto acabado e estoques de materiais para manutenção, reparo e operação. 
Figura 3 - Alguns motivos para o surgimento dos estoques

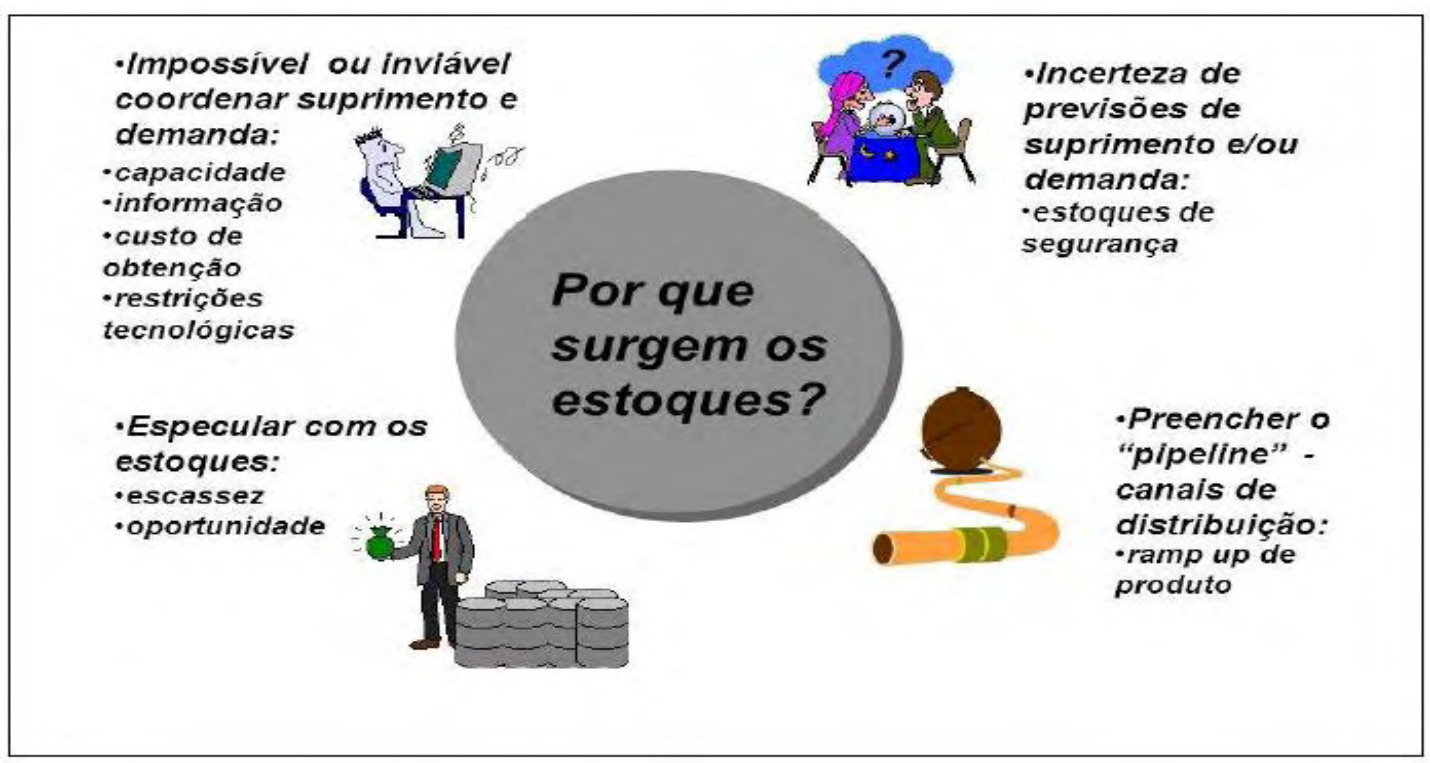

Fonte: CORRÊA, H. L.; GIANESI, I. G. N.; CAON, M. Planejamento, programação e controle da produção: MRP II / ERP: conceitos, uso e implantação: base para SAP, Oracle Applications e outros softwares integrados de gestão. $-5^{\underline{a}}$ Ed.- $2^{\underline{a}}$ reimpr. - São Paulo: Atlas, 2008.

Visto isto, pode-se afirmar que os estoques são umas das maiores preocupações dos gestores operacionais, financeiros, comerciais e fabris (Figura 4). A gestão adequada do estoque reflete na organização empresarial, visando o completo atendimento das necessidades da empresa e buscando gerar o maior lucro possível. Desse modo, gerir o estoque é buscar o equilíbrio entre a demanda e o consumo, para que se tenha os recursos necessários, na quantidade necessária e no momento necessário (CORRÊA; CORRÊA, 2000; VIANA, 2000). 
Figura 4 - Gestão de estoques (física e estratégica)

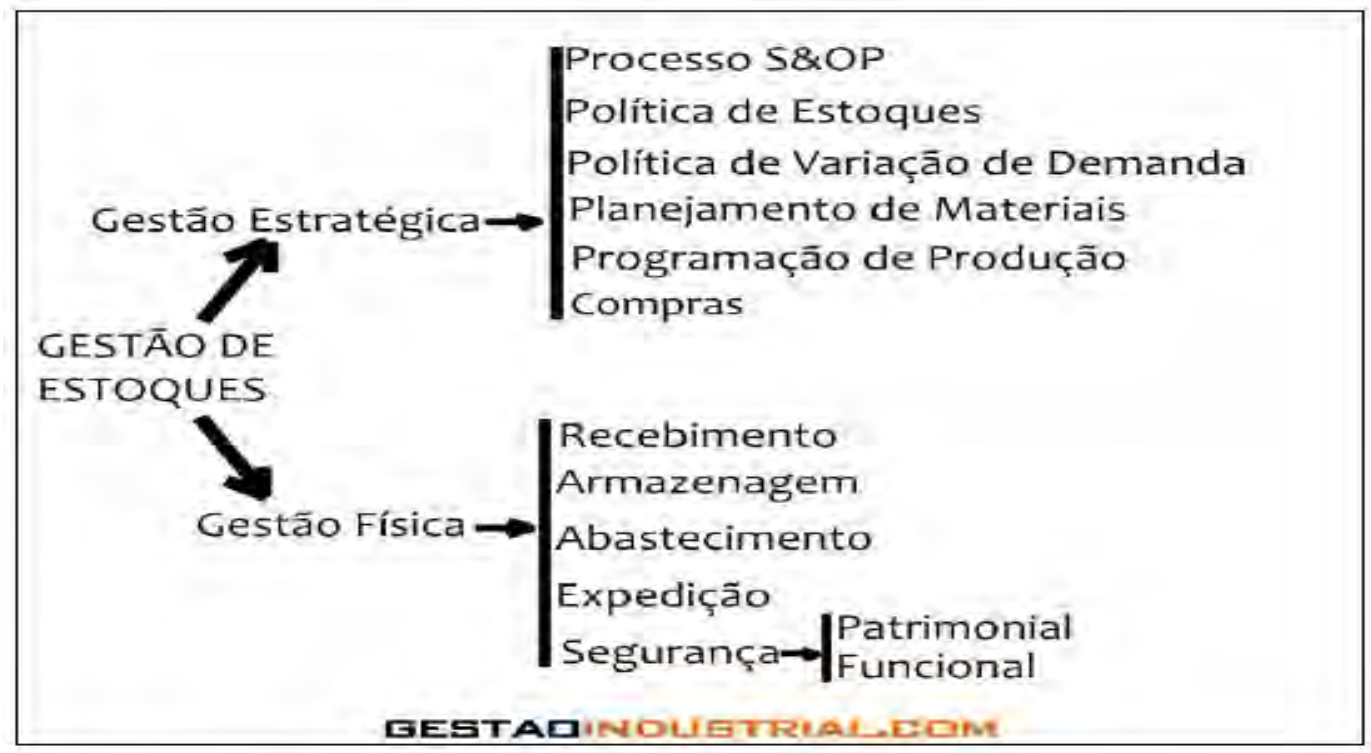

Fonte: VARGAS, R. Gestão de Estoques. Disponível em: <http://www.gestaoindustrial.com/index.php/industrial/logistica/gestao-de-estoques >. Acesso em 10/07/2019

\subsubsection{Ferramentas para gestão de estoques}

\subsubsection{Curva ABC}

A maneira mais comum de controlar os estoques utiliza a classificação ABC (Figura 5). Essa ferramenta utiliza o princípio básico de Pareto para distinguir diferentes valores ou significâncias relacionadas aos tipos de estoques. Na curva ABC, classifica-se o estoque de acordo com o seu grau de importância para a organização, seja pelo elevado volume de vendas ou pelo alto valor agregado na margem de contribuição. Desta forma e através de Pareto, é possível efetuar a classificação $A B C$ seguindo os requisitos básicos abaixo (DE AGUIAR; DE OLIVEIRA; CERVI, 2017):

- Itens classe A representam $20 \%$ dos produtos contidos no estoque, porém, que bancam cerca de $80 \%$ do valor total do estoque;

- Itens classe B são considerados de valor mediano, representam 30\% dos produtos e bancam cerca de $10 \%$ do valor total do estoque; 
- Itens classe $\mathrm{C}$ são considerados itens de baixo valor agregado, bancam aproximadamente cerca de $10 \%$ do valor total do estoque, no entanto, representam $50 \%$ dos produtos contidos no estoque.

Figura 5 - Exemplo de Curva ABC

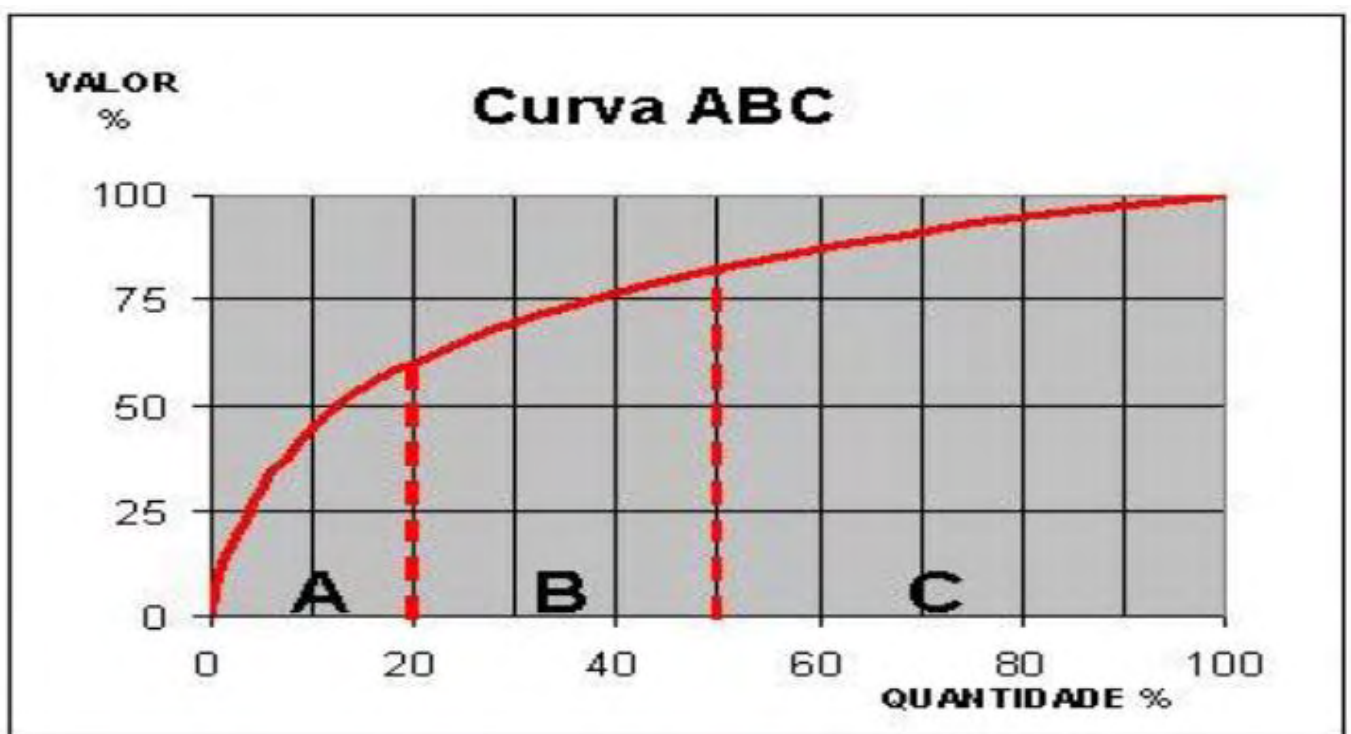

Fonte: SLACK, N.; CHAMBERS, S.; JOHNSTON, R. Administração da produção. São Paulo: Atlas, 2009.

De acordo com Viana (2000), a curva $A B C$ é uma importante ferramenta para gerir estoques, pois através dela é possível identificar itens que precisam de uma maior atenção no planejamento de suprimentos. Reforça ainda que a classificação pode ser feita de várias maneiras, sendo considerados aspectos como o tempo de reposição, valor de demanda e consumo, entre outros. Leal, Cotrim e Nardotto (2016), também apontaram que esse método proporciona cálculos de custos mais assertivos tanto para as atividades, quanto para os produtos, e dessa maneira, é capaz de oferecer informações mais precisas em relação às operações realizadas na organização, além de uma melhor definição de custo sobre cada produto.

\subsubsection{Warehouse Management System (WMS)}

O sistema Warehouse Management System (WMS) surgiu para suprir as novas exigências do mercado, no qual os pedidos de compra tornaram-se menores e mais frequentes. Sendo assim, a indústria foi forçada a trabalhar com um menor ciclo do pedido, chamado lead time, que é o tempo decorrido desde a efetivação do pedido 
pelo consumidor até a entrega do produto ou serviço (SLACK; CHAMBERS; JOHNSTON, 2009).

Devido a trabalhar-se com níveis de estoque mais baixos, os clientes exigem mais agilidade e demandam menor tempo de resposta dos seus fornecedores que, por sua vez, precisam diminuir o seu ciclo de pedido, tornando-o mais veloz sem comprometer a qualidade do processo. Neste cenário, os pedidos recebidos incompletos ou errados têm maior probabilidade de levar à falta de produtos e perdas de venda, o que faz a tolerância a erros ser praticamente nula (SLACK; CHAMBERS; JOHNSTON, 2009).

Visto isso, se fez necessário o gerenciamento de forma eficiente das atividades operacionais, utilizando sistemas de informação logística ou de gerenciamento da cadeia de suprimentos que têm como objetivo aprimorar a capacidade operacional do armazém no qual é aplicado, a partir de duas formas: aumentando o seu tamanho ou aumentando o giro dos produtos, fazendo com que eles permaneçam o menor tempo no armazém (BANZATO, 2016; PEREIRA et al., 2016).

Uma das maneiras de obter tal agilidade é através da implantação do sistema WMS que, segundo Rodrigues et al. (2010), pode ser definido como a integração entre hardware, software e equipamentos periféricos para gerenciar o estoque, o espaço físico, os equipamentos utilizados na movimentação interna e auxiliar os colaboradores que atuam nesta área. De acordo com Banzato (2016), o WMS também pode ser explicado como um modelo de gestão de armazém, que otimiza as atividades operacionais, como o fluxo de materiais, as atividades administrativas e o fluxo de informações, dentro do processo de armazenagem, atuando sobre o recebimento, a estocagem, a separação de pedidos, a expedição e o inventário.

Dessa forma, a implantação do WMS pode proporcionar à empresa o aumento da precisão das informações de estoque, a ampliação da velocidade e qualidade das operações do armazém e o incremento da produtividade dos colaboradores e dos equipamentos envolvidos neste processo (DA SILVA COSTA; JÚNIOR, 2008).

Porém, de acordo com Banzato et al. (2003), a alta quantia para investimento inicial, o baixo conhecimento dos colaboradores sobre a ferramenta, a resistência à mudança, necessidade de remodelagem e adaptação dos processos operacionais, 
assim como a integração entre hardware, software e os funcionários podem ser consideradas como dificuldades na implantação do sistema. Assim que superadas essas dificuldades, o WMS pode auxiliar a empresa na redução dos seus custos operacionais e na melhoria do nível de serviço prestado. Destacam-se a melhoria da precisão de inventário, melhoria da ocupação do espaço, redução de erros operacionais, aumento da produtividade, redução do tempo de pedido em espera e otimização de percurso de separação de pedidos (BANZATO et al., 2003; BANZATO, 2016).

\subsection{Previsões de demandas}

Prever o comportamento do mercado é um trabalho dos mais difíceis de executar (Figura 6). Devido a isso, organizações que possuem uma grande diversidade de produtos em seu portifólio convivem com problemas pertinentes à gestão de estoques, à previsão de demanda e ao planejamento e controle da produção (DOS SANTOS et al., 2018). A previsão de demanda é importante para que as atividades do processo de produção sejam adequadamente programadas e realizadas, incluindo uso de mão de obra e reposição de materiais no momento e quantidade certa (COSTA; DE SANTANA; FERNANDES, 2017).

Figura 6 - Elementos principais para a gestão de demanda

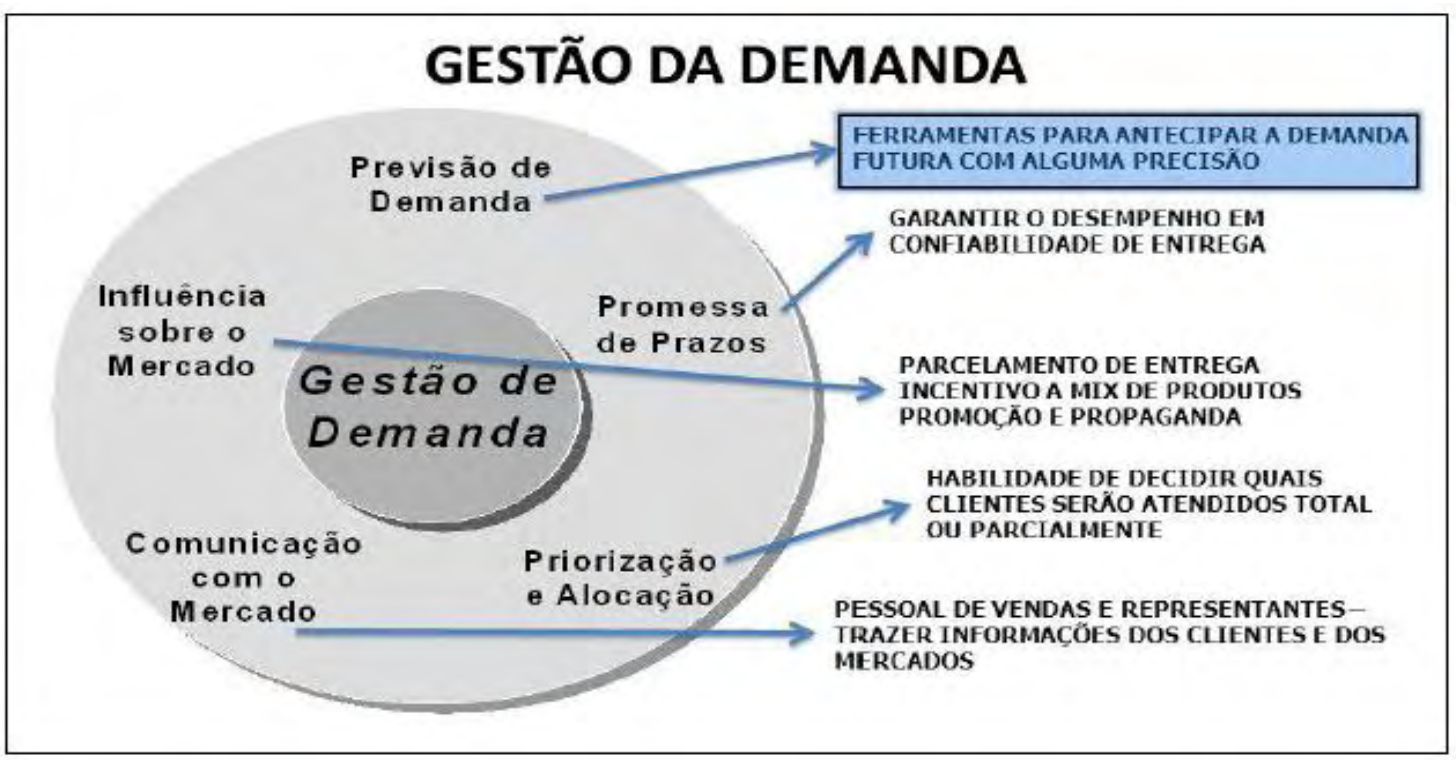

Fonte: CORRÊA, H. L.; GIANESI, I. G. N.; CAON, M. Planejamento, programação e controle da produção: MRP II / ERP: conceitos, uso e implantação: base para SAP, Oracle Applications e outros softwares integrados de gestão. - 5 ${ }^{\mathrm{a}}$ Ed.- $2^{\mathrm{a}}$ reimpr. - São Paulo: Atlas, 2008. 
$\mathrm{Na}$ maior parte das organizações, a previsão de demanda é de responsabilidade dos departamentos de vendas e/ou marketing. Entretanto, considera-se a previsão de demanda como o principal insumo para tomada de decisão do planejamento e controle da produção (CORRÊA; GIANESI; CAON, 2008). Segundo os autores, para que a previsão de demanda seja assertiva e não implique em erros que impactam diretamente na capacidade produtiva e/ou capacidade de armazenagem, a previsão da demanda precisa seguir três requisitos básicos:

i. Ser expressa em termos úteis para o planejamento e controle da capacidade produtiva;

ii. Ser tão exata quanto o possível;

iii. Dar uma indicação da incerteza relativa.

Outro ponto que merece grande atenção é em relação as sazonalidades, pois quase todos os produtos e serviços têm alguma sazonalidade na demanda, então, essas sazonalidades podem ser razoavelmente previsíveis, exceto por grandes variações climáticas ou econômicas (COSTA; DE SANTANA; FERNANDES, 2017).

Demanda dependente é a demanda que é relativamente previsível devido a sua dependência de alguns fatores conhecidos. Demanda independente é a operação que terá que suprir a demanda sem ter qualquer visibilidade firme antecipada dos pedidos dos consumidores, segundo Slack, Chambers e Johnston (2009). Segundo os mesmos autores, o planejamento e o controle da produção requerem a conciliação do suprimento e da demanda em termos de volume, tempo e qualidade.

\subsection{Previsão de vendas}

O processo de previsão de vendas pode ser considerado o mais importante dentro da gestão da demanda. O levantamento de informações prevê o histórico de vendas e o comportamento do mercado, além de informações sobre concorrentes, situações dos clientes quanto a intenção de compra e níveis de estoque, situação econômica atual e futura, entre outras informações. Com isso, pode-se gerar dados que são analisados e cujas variáveis podem ser tratadas estatisticamente (CORRÊA et al., 2001). A Figura 7 mostra o sistema que deve ser gerado para ser feita uma previsão mais assertiva. 
Figura 7 - Sistema de previsão de venda

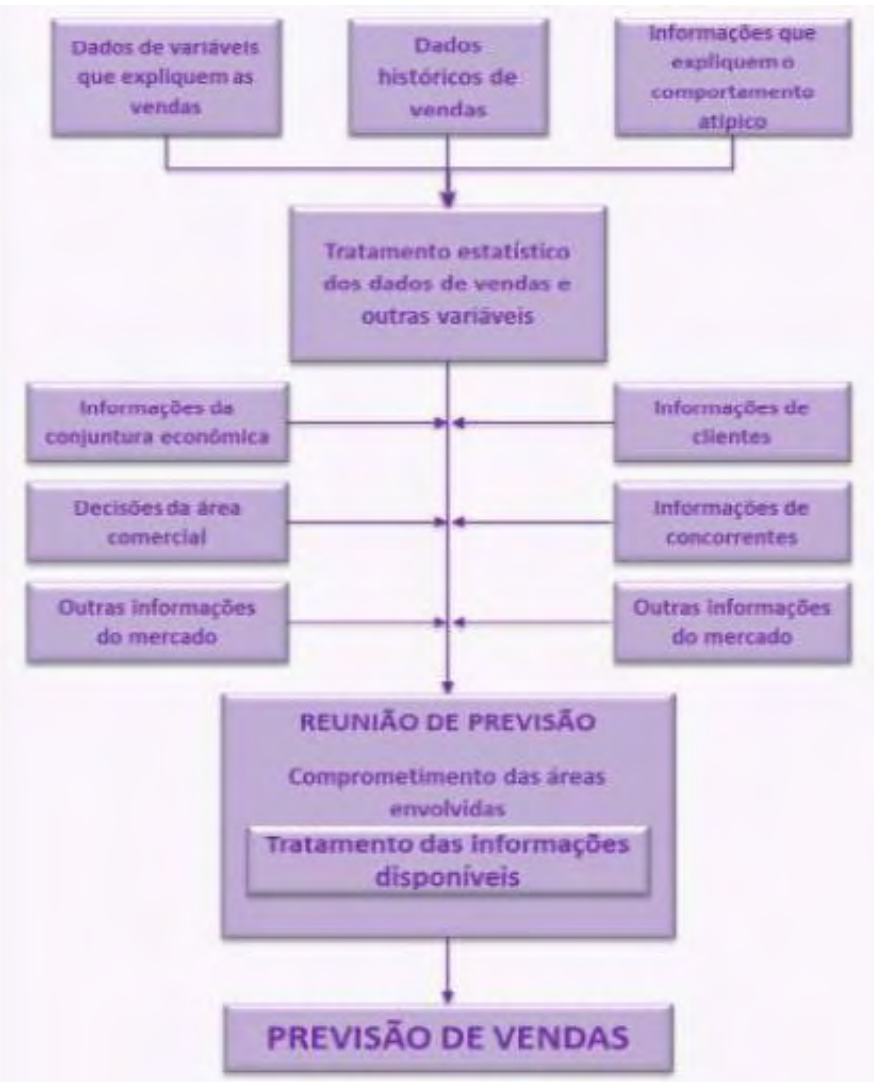

Fonte: CORRÊA, H. L.; GIANESI, I. G. N.; CAON, M. Planejamento, programação e controle da produção: MRP II / ERP: conceitos, uso e implantação: base para SAP, Oracle Applications e outros softwares integrados de gestão. $-5^{\mathrm{a}}$ Ed.- $2^{\mathrm{a}}$ reimpr. - São Paulo: Atlas, 2008.

De acordo com Moreira (2001), há dois métodos de previsão: qualitativos e matemáticos. Os métodos qualitativos são baseados no julgamento de pessoas que, direta ou indiretamente, são capazes de opinar sobre a demanda futura, como gerentes, departamento de vendas, clientes, entre outros. Os métodos matemáticos são utilizados a partir de modelos matemáticos para chegar a valores previstos. Esses métodos são subdivididos em a) causais, ou seja, demanda relacionada a uma ou mais variáveis internas ou externas e, b) séries temporais, caracterizado pelo conhecimento de valores passados da demanda.

\subsection{Ferramenta para previsão de demanda - Enterprise Resource Planning (ERP)}

Alinhado com o MRP, desenvolveu-se o Planejamento de Recurso do Empreendimento (ERP) que integra as atividades de planejamento, vendas e marketing, finanças e recursos humanos. O ERP permite que as decisões e a base 
de dados de todas as partes de uma organização sejam integrados, de modo que as consequências das decisões de uma parte da organização sejam refletidas nos sistemas de planejamento e controle do restante da organização (SLACK; CHAMBERS; JOHNSTON, 2009).

Nesse sistema, são determinadas as quantidades e períodos para a fabricação/aquisição de cada item, além de calcular os recursos necessários, por exemplo, a capacidade de máquinas e equipamentos, mão de obra, recursos financeiros, etc. O ERP representa uma evolução do sistema MRP (CORRÊA; CORRÊA, 2000).

Ainda, segundo Ramos e Oliveira (2002), o sistema ERP busca gerar e/ou receber informações imediatas dos módulos dependentes, com o intuito de agilizar o processo de tomada de decisões referentes à manufatura, abastecimento, financeiro ou recursos humanos. Com isso, o sistema proporciona a visualização ampla do cenário que envolve os negócios da empresa.

\subsection{Gerenciamento de processos de negócios}

Um processo, de acordo com Oliveira et al. (2006), pode ser definido por um conjunto de ações ordenadas e integradas para se obter um resultado específico, podendo ser um bem ou um serviço. Ainda, segundo Davenport (1993), também pode ser entendido como o desempenho de uma atividade ou um conjunto de ações, no qual ocorra uma entrada, uma transformação e uma saída, e assim objetiva-se alcançar metas.

Desse modo, os processos são importantes, porque é através deles que as empresas exercem suas funções, já que todo e qualquer trabalho realizado nas empresas, fazem parte de algum processo (DAVENPORT, 1993; OLIVEIRA et al., 2006).

O processo de negócio de uma empresa passou a ser uma unidade na qual os processos e recursos que o compõem são organizados para o fim de um bem ou serviço. Ele fundamenta-se em cinco elementos voltados para o desenvolvimento de atividades com seus clientes. Estas atividades são voltadas para a criação de valor para os clientes e são operadas por fatores ou sistemas que podem ser pessoas ou 
máquinas e, frequentemente, envolvem várias unidades organizacionais que são responsáveis por todo o processo (OLIVEIRA et al., 2006). Em síntese, os autores reforçam a ideia de que o processo de negócio consiste num conjunto estruturado de atividades, com a função de produzir resultados específicos para uma determinada área, utilizando os passos projetados para obter um produto ou serviço. Assim, as empresas podem ser vistas como um todo e não como uma junção de partes isoladas, fazendo possível a integração de uma empresa via sistemas de informação através do modo de interpretar a organização como um todo.

Nesse contexto, configura-se o Business Process Management (BPM) ou Gerenciamento de Processos de Negócios, que consiste em um método de gestão para gerenciar processos empresariais, que conta com o auxílio de ferramentas tecnológicas, o que permite que as organizações criem valor por meio do funcionamento da empresa em função de todos os seus processos. O BPM é um conceito que une gestão de negócios e tecnologia da informação, visando a melhoria dos processos de negócios das organizações através do uso de métodos e de ferramentas que servem para modelar, analisar, publicar e controlar os aspectos estratégicos, organizacionais, sistemas tecnológicos e humanos, ou seja, engloba de forma integrativa todo o trabalho executado para entregar um produto ou serviço, independentemente de quais áreas funcionais estejam envolvidas (ABPMP, 2013; BARCELOS et al., 2017).

Fazer uso do sistema BPM significa administrar o ciclo de vida completo do processo, o qual envolve as fases de desempenho, implantação, monitoramento e otimização do processo. Segundo Barcelos et al. (2017), é possível afirmar que a ferramenta contribui positivamente para a qualidade das informações, e consequentemente, possui influência direta nos resultados. Assim, o sistema também pode ser entendido como uma disciplina metodológica para implantar melhorias e práticas de métricas, indicadores chave de desempenho, colaboração e gestão de mudança (OLIVEIRA et al., 2006).

\subsection{Modelagem}

A modelagem é uma etapa importante do gerenciamento de processos de negócios. Ela consiste em um conjunto de práticas e tarefas que as empresas devem 
executar para descrever visualmente todos os aspectos do processo, incluindo o seu curso, controle e pontos de decisão, gatilhos e condições para execução das atividades, ou seja, o contexto em que uma atividade executa e os recursos associados (JOSUTTIS, 2008).

Através da modelagem, pode-se construir formas gráficas que serão analisadas e melhoradas pela gestão empresarial. A partir disso, é possível visualizar o processo de negócio em seu estado atual, chamado As ls (como é) e, após analisado, representar como ficará com a alteração do processo, chamado To Be (como será); para isso é necessário entender informações como tempo, recursos e custos (BALDAM et al., 2009).

Para construir a modelagem do processo, uma das ferramentas mais usadas são os fluxogramas. Eles são formados por um grupo simples de formas para simbolizar operações, decisões e outros aspectos de processos (MÜLLER, 2003). O fluxo de informação, representado por meio de símbolos, tem a função de abranger todos os setores da organização, percorrendo informações desde a cadeia de produção, setor de vendas, marketing, finanças, projetos, compras, planejamento, recursos humanos, suprimentos e produção (PEDROSO et al., 2016). 
Figura 8 - Fluxograma: Como amarrar os sapatos?

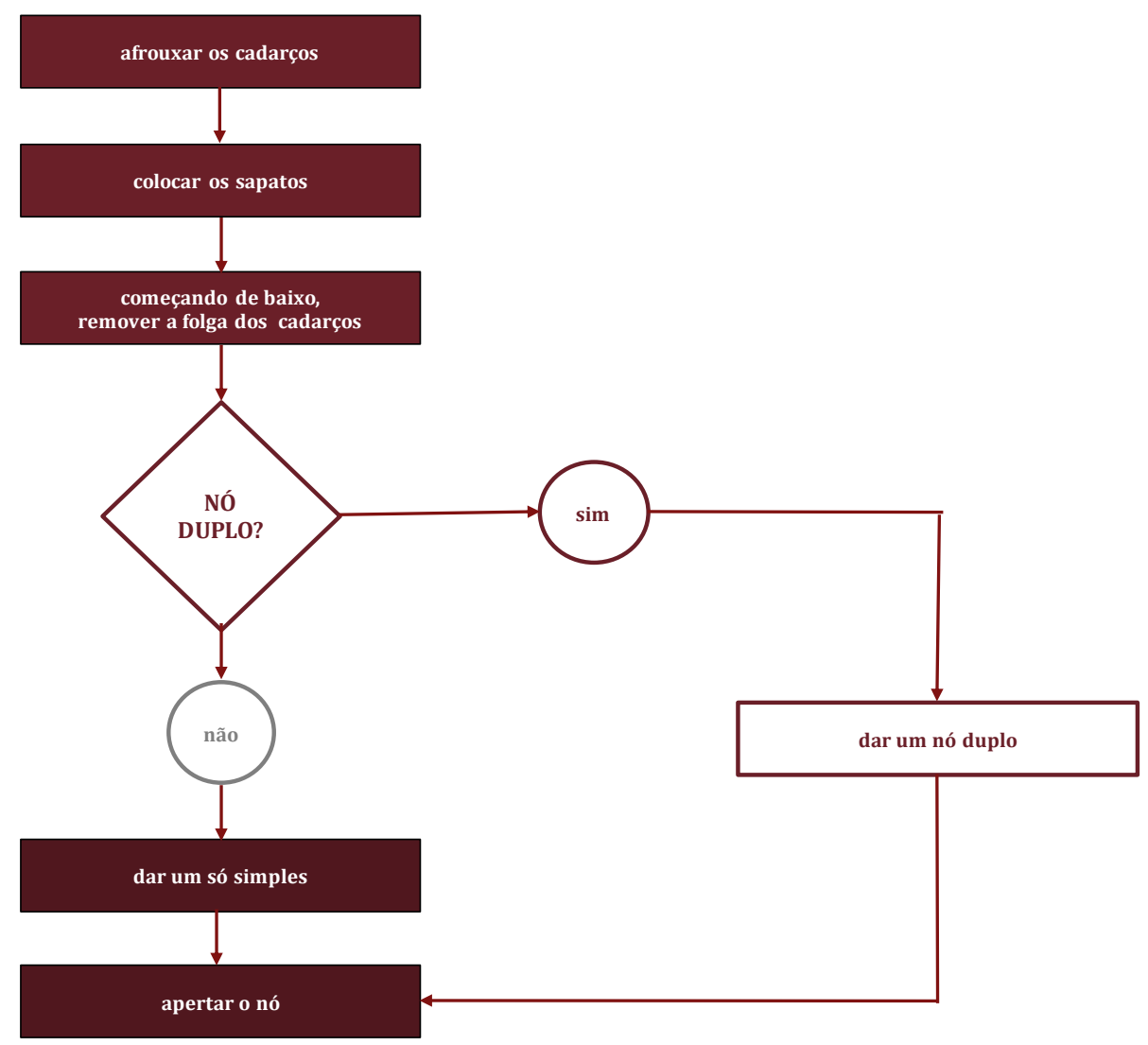

Fonte: Própria autoria.

O fluxograma hipotético e utilizado apenas como um exemplo didático da Figura 8, foi padronizado de maneira que os símbolos de início e fim, geralmente são representados por retângulos; as setas provenientes de um processo direcionados a outro indicam que a responsabilidade passa de um símbolo ao outro; os passos de processamento são representados como retângulos; a decisão é representada como losango, contendo Sim/Não; e pode ou não conter raias à margem da representação gráfica, tipificando os responsáveis por um conjunto de processos (ABPMP, 2013).

\subsubsection{Análise de processos}

O entendimento das etapas e características de cada processo só é possível através de uma ferramenta chamada análise de processos. A partir dela podem ser realizadas melhorias no processamento, compreender as mudanças regulatórias e, principalmente, administrar o risco inerente a qualquer atividade organizacional (ABPMP, 2013). 
Os riscos em processos podem ser analisados e classificados em graus diferentes de detalhamento, o que dependerá da criticidade dos ativos, do tamanho das vulnerabilidades e dos incidentes anteriores envolvendo os processos. A metodologia para avaliar tais riscos pode ser caracterizada de forma qualitativa, a qual normalmente é realizada em um primeiro momento, e de forma quantitativa, feita em seguida para refinar a análise dos riscos mais expoentes indicados pela primeira análise (ABNT, 2011).

Por meio da identificação dos riscos nos processos podem ser avaliados os possíveis impactos e a probabilidade de ocorrência e, assim, construir uma matriz de priorização de riscos que auxiliam a visualização do impacto que determinado risco pode causar, como também, auxilia nas decisões a serem tomadas para solucionálos (IFAC, 1999).

A análise de processos de negócios se mostra fundamental para a eficiência no gerenciamento, indicando os processos mais críticos e com maior demanda de ajustes priorizados, além de incluir a previsão de mudanças, necessidades e expectativas dos envolvidos organizacionalmente (ABPMP, 2013).

\subsubsection{Redesenho}

O redesenho de processos de negócio baseia-se em repensar e reestruturar um processo, provocando melhorias significativas nos indicadores de desempenho das organizações, em termos de custo, qualidade, serviço e velocidade (HAMMER; CHAMPY; KORYTOWSKI, 1994). Ainda, neste sentido, de acordo com Harrington, Esseling e Nimwegen (1997), o redesenho de processos também pode ser entendido como a soma dos esforços dos gestores para refinar um processo atual. Ele pode impactar na redução de custos, de tempo de ciclo e de taxa de erros entre 30 e 60\%, podendo ser feito na maioria dos processos em uso.

As metodologias de redesenho de processos de negócios visam maximizar o valor adicionado por um processo de negócios (SAWY, 2001). Este pode ser avaliado por medidas de desempenho, como rapidez, produtividade, custo e satisfação dos clientes, e pelo retorno sobre investimento. Neste sentido, um projeto de redesenho baseia-se na atualização das regras e funcionamentos que estavam orientando as operações de uma empresa (LONGARAY et al., 2018). Para isso, as metodologias 
geralmente definem cinco estágios para execução de um projeto de redesenho (DAVENPORT, 1993; KETTINGER; TENG; GUHA, 1997; SAWY, 2001):

a) Desenvolvimento da visão estratégica do negócio e de objetivos compatíveis para os processos de negócio da empresa;

b) Mobilização de recursos e pessoas para a execução do projeto de redesenho;

c) Análise e redesenho dos processos;

d) Implantação dos novos processos e ajuste da organização;

e) Acompanhamento do desempenho e refinamento dos novos processos.

Essas metodologias, segundo Sawy (2001), devem visar o princípio da minimização do "lixo", que é o trabalho que não agrega valor para o cliente do processo, através da eliminação de atividades ultrapassadas, da consolidação de atividades similares e da simplificação de procedimentos.

Para a reestruturação de processos é necessário que seja feita uma visão orientada que vá além das atividades executadas dentro de um único departamento. Essa reestruturação deve também contemplar o fluxo de produtos, serviços e informações entre departamentos. Contudo, a essência de um redesenho de processos de negócios é a identificação e a quebra de regras e fundamentos obsoletos que ainda orientam as operações de uma empresa, visando assim o alcance de metas, as estratégias organizacionais e trazendo a satisfação do cliente para dentro da empresa (MORENO; SANTOS, 2012). 


\section{MATERIAL E MÉTODOS}

\subsection{Caracterização da pesquisa}

De acordo com Kirsch e Lemes (2019) e Koerich et al. (2017), esta pesquisa caracteriza-se como: a) Pela natureza: como pesquisa aplicada, com o objetivo de gerar conhecimentos para aplicação prática na solução de problemas relacionados à gestão de PCP; b) Quanto aos objetivos: pesquisa ação, pois envolve o levantamento de dados, identificação do problema dentro da organização, levantamento de possíveis soluções e a intervenção prática na gestão do setor; c) Quanto à abordagem do problema: pesquisa qualitativa, ao buscar reconhecer as informações sobre os fluxogramas original e proposto para a melhoria das atividades fins do PCP; d) Quanto aos procedimentos técnicos: foram utilizados referencial bibliográfico e modelagem/simulação do case em questão; e) Como Instrumento e coleta de dados: a pesquisa utilizou-se de dados reais da organização de PCP de uma empresa de nutrição animal; e, f) Para a análise de dados foi utilizada os fluxogramas preconizados na técnica de gerenciamento de processos de negócio referentes aos problemas investigados.

\subsection{Caracterização do objeto de estudo}

O trabalho foi desenvolvido através de um estudo de caso real de uma indústria no ramo da nutrição animal, localizada em Descalvado/SP. Para a obtenção dos dados preliminares foram pesquisados conceitos teóricos e ferramentas na literatura para poder definir o melhor método a ser seguido para o planejamento e controle de produção dentro da referida empresa. A coleta de dados foi realizada por um levantamento de dados no departamento de PCP e, também, de departamentos envolvidos, direta ou indiretamente, com o PCP da empresa, por meio de uma pesquisa ação e alinhada ao conhecimento tácito do pesquisador, por experiência profissional.

A pesquisa teve abordagem qualitativa, pois esse processo metodológico abriga diversas técnicas que procuram descrever e traduzir a questão principal, promovendo o delineamento do problema. $\mathrm{O}$ método qualitativo é mais direcionado à compreensão dos fatos do que à mensuração de fenômenos (YIN, 2001). 
A pesquisa de natureza qualitativa é aderente aos estudos de assuntos complexos, permitindo que o pesquisador obtenha informações mais detalhadas e trabalhe com mais profundidade a questão estudada. A maior vantagem neste tipo de pesquisa reside na riqueza dos detalhes obtidos. Os procedimentos metodológicos para a realização da pesquisa podem ser sintetizados na Figura 9.

Figura 9 - Sequência das atividades de pesquisa
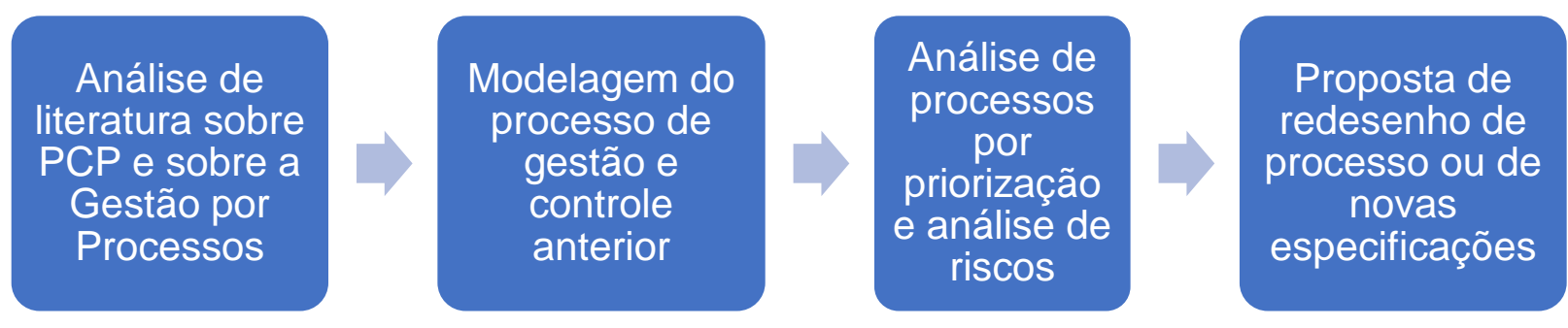

Fonte: Própria autoria.

A pesquisa iniciou-se pela análise de literatura de artigos científicos e livros, para um detalhamento sobre a temática de PCP e da gestão por processos de negócios que podem ter aderência numa proposta de melhoria de gerenciamento do controle na empresa.

\subsection{Técnica de análise dos dados}

Nesse sentido, foi desenvolvido o processo de negócios utilizando-se da ferramenta do Fluxograma, com o propósito de representar graficamente as atividades e os seus responsáveis. Na sequência, foram descritas as relações existentes para melhor compreensão e entendimento do processo.

A partir disso, foi realizada a análise dos processos de controle no estudo de caso, modelados a partir das informações reais da gestão da empresa. Através das ferramentas de análise processual, foram elencadas as atividades mais críticas por intermédio da aplicação da sistemática presente na documentação da Associação Brasileira de Normas Técnicas (ABNT, 2011) e da International Federation of Accountants (IFAC, 1999). Ao final foi executada a análise de riscos.

Para a visualização da criticidade das atividades do processo de produção e controle da empresa, foi construída uma matriz de priorização. As atividades foram 
posicionadas em virtude da probabilidade de ocorrência do risco gerado no processo de negócio somado ao impacto da consecução desse mesmo risco. As atividades constantes nas áreas mais críticas da matriz, simbolizadas pela cor vermelha, serão analisadas prioritariamente, seguidas pelas atividades de média probabilidade e impacto, simbolizadas pela cor amarela, e, após, serão analisadas as atividades que se classificam como de baixo impacto e probabilidade, classificadas pela cor verde (Figura 10).

Figura 10 - Matriz de Priorização de Riscos em Processos

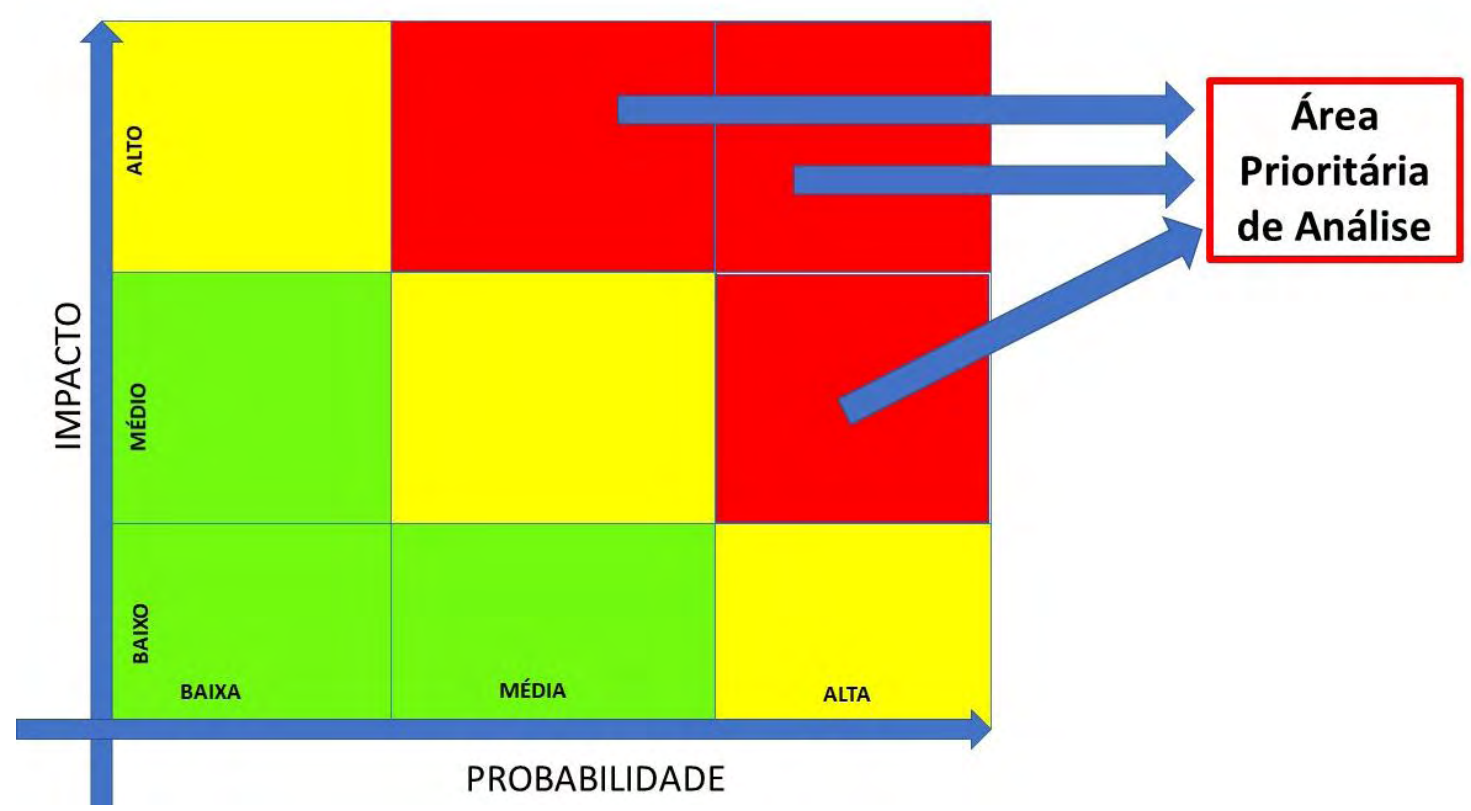

Fonte: Adaptado de INTERNATIONAL FEDERATION OF ACCOUNTANTS - IFAC. Enhancing sharehold wealth by better managing business risk. New York: FMAC,1999.

A análise das informações foi feita a partir de tabulações realizadas no Excel, caracterizando como é realizado o planejamento de controle de produção dentro da indústria e como poderia ser com novas ferramentas incrementadas. Com isso, espera-se que o conjunto de propostas de melhoria exponha a importância do PCP dentro da organização, além de identificar os fatores que podem ser benéficos ou prejudiciais no planejamento e controle da produção.

A busca de informações da pesquisa foi desenvolvida em cinco fases, descritas a seguir: 
1. Conhecimento da empresa, por meio da análise da missão, visão e valores da companhia, com consequente verificação e avaliação do processo produtivo da organização;

2. Verificação de como é feito o planejamento e o controle da produção, quais as suas atividades principais e qual o posicionamento do PCP frente as demandas do dia a dia;

3. Análise da capacidade produtiva, da capacidade de estoque e da quantidade de produtos a fim de propor melhorias para o planejamento e controle da produção, além de sugerir melhorias para a gestão de estoques;

4. Verificação do histórico de vendas da companhia e de como são feitas as previsões de demanda no intuito de progredir e ter maior acurácia nas previsões;

5. Proposta de redesenho operacional baseado na análise de processos de negócios na gestão estratégica de uma indústria de nutrição animal. 


\section{RESULTADOS E DISCUSSÃO}

De acordo com o significado da palavra Gestão no dicionário, "ato ou efeito de gerir", foi possível analisar e detalhar a pesquisa ação de forma com que fosse denominado o modelo de gestão ao qual a empresa avaliada no estudo de caso geria.

Para a proposta da realização de redesenho de processos, algumas etapas são fundamentais, como citadas por Baldam et al. (2009). Então, foi realizada uma pesquisa exploratória na estrutura organizacional da empresa, pela qual identificouse as funções de cada setor da organização, como proposto por Pedroso et al (2016) e, a partir desse ponto, foi possível construir a modelagem do processo para seu gerenciamento, em comum acordo com Josuttis (2008).

Com a visualização dos processos, foi plausível analisá-los para o entendimento de cada etapa e suas características, além de poder identificar seus riscos e classificar as atividades desenvolvidas pelo departamento de PCP quanto ao seu grau de impacto e probabilidade, de acordo com o descrito pela ABNT (2011), ABPMP (2013) e IFAC (1999).

Por fim, foi realizada a proposta de redesenho de processos de negócios, por meio da reestruturação e atualização do processo de produção, com fundamentação conceitual descrito nas referências Davenport (1993), Hammer, Champy e Korytowski (1994), Harrington, Esseling e Nimwegen (1997), Kettinger, Teng e Guha (1997), Sawy (2001) e Longaray et al. (2018).

\subsection{Modelagem da Gestão Empresarial}

Desta forma, pode-se assegurar que 0 modelo de gestão utilizado anteriormente não era o mais indicado estratégica e gerencialmente para obter resultados satisfatórios, pois considerava-se a produção como eixo central da organização (Figura 11). Sendo assim, todo o planejamento era baseado na produção, ou seja, visando sempre a produtividade independente dos departamentos que participavam direta ou indiretamente do processo produtivo. 
Figura 11 - Eixo Central da Organização - Gestão Anterior

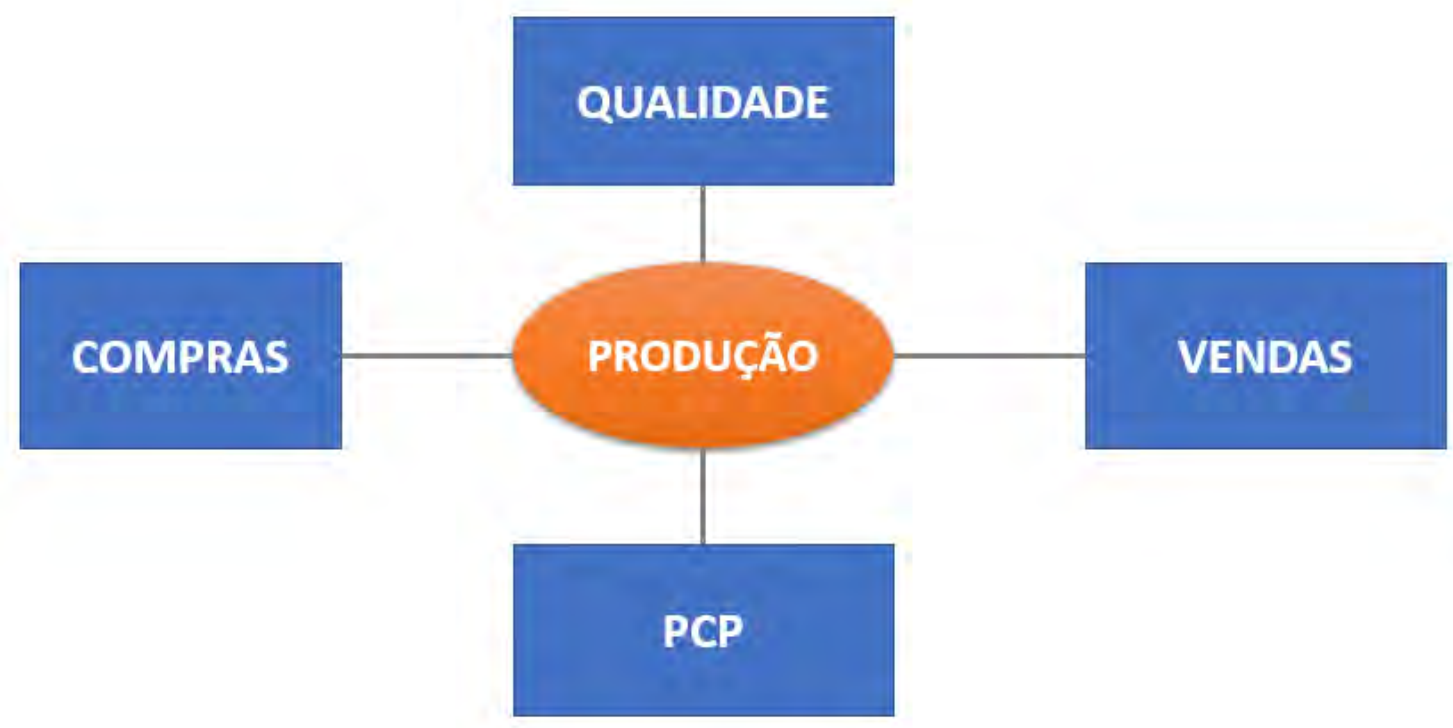

Fonte: Própria autoria.

$\mathrm{Na}$ administração atual, a gestão estratégica organizacional foi bastante estudada por meio dos conceitos teóricos e discutida em reuniões e entrevistas com diretores, gestores e supervisores, os quais apresentavam experiência e conhecimento específicos sobre o ramo, tornando possível unir os conceitos e reestruturar o modelo de gestão da Organização.

A partir da reestruturação pretendida, tem-se a necessidade de se organizar e gerenciar o planejamento e o controle da produção com o objetivo de satisfazer as demandas dos clientes, pois, de acordo com Slack, Chambers e Johnston (2009), "toda atividade produtiva requer planos e requer controle, embora o grau de formalidade e os detalhes possam variar".

Assim, o PCP apresenta-se em destaque, já que é o responsável por planejar e controlar a produção. Apoiando-se em Kumar e Sinha (1999), passa a ser o eixo operacional da organização e é visto como importante e estratégica função dentro da Organização (Figura 12). Da mesma maneira verificaram em Pedroso et al. (2016) e Da Silva, Duarte e Da Silva (2019) que identificaram a presença de atividades do PCP em vários setores da organização, comprovando que este departamento é a base da gestão. 
Figura 12 - Redesenho do Eixo Central da Organização - Gestão Atual

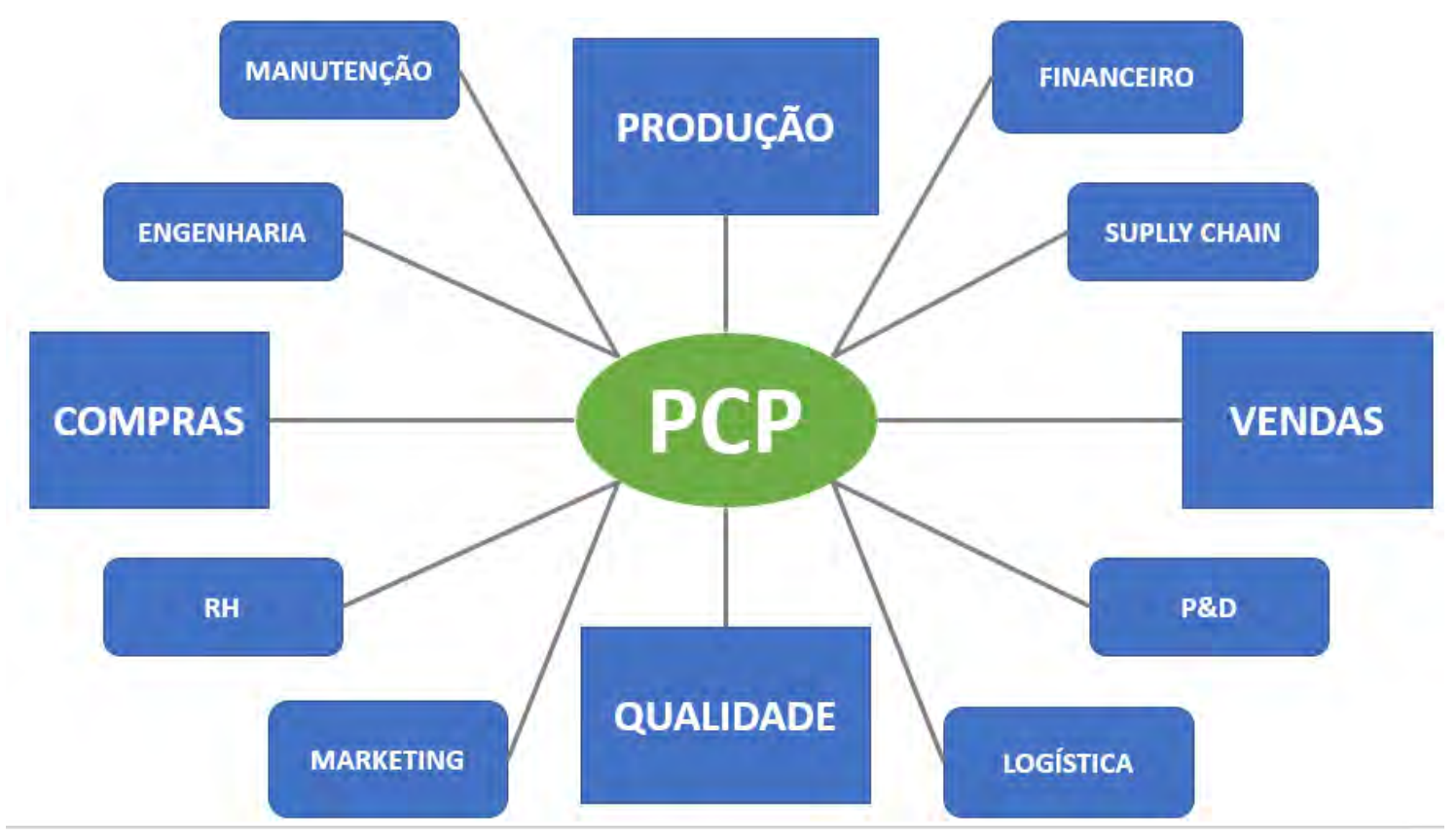

Fonte: Própria autoria

\subsection{Estrutura Organizacional da Empresa}

Durante o processo de reestruturação, assimilou-se também a necessidade de se modificar a estrutura organizacional de forma com que fossem mantidos os princípios e valores da Companhia. Estes princípios visam garantir a qualidade, segurança e rastreabilidade do alimento, combinando inovação e uso sustentável dos recursos, assim como avaliar a segurança e a vida de seus colaboradores, os quais são as peças mais importantes para que o resultado seja alcançado. Contudo, ocorreram modificações dos departamentos e, automaticamente, nos superiores diretos de cada área específica da empresa, pois na configuração anterior alguns departamentos respondiam diretamente para o mesmo superior (Figura 13), o que na teoria é considerado incorreto, visto que pode haver falhas nos momentos de decisões críticas, acarretando possíveis desconfortos. 
Figura 13 - Estrutura Organizacional - Gestão Anterior

\begin{tabular}{|c|c|c|c|c|}
\hline \multicolumn{5}{|c|}{ PRESIDÊNCIA } \\
\hline \multicolumn{2}{|c|}{ DIRETOR INDUSTRIAL } & DIRETOR DE COMPRAS & \multicolumn{2}{|c|}{ DIRETOR DE VENDAS } \\
\hline GERENTE DE PRODUCÃA & SUPERVISOR DE QUALLDADE & GERENTE DE COMPRAS & GERENTE DE VENDAS & SUPERVISOR DE LOGISTICA \\
\hline $\begin{array}{l}\text { PCP } \\
\text { SUPERVISORES DE PRODUÇÃO } \\
\text { SEGURANÇA DO TRABALHO } \\
\text { FUNCIONÁRIOS DA PRODUÇÃO }\end{array}$ & ANALISTAS DA QUALIDADE & $\begin{array}{l}\text { COMPRADORES } \\
\text { AUXILIARES }\end{array}$ & VENDEDORES & ANALISTAS \\
\hline
\end{tabular}

Fonte: Própria autoria.

No entanto, as mudanças foram necessárias e neste processo abriram-se as portas para uma nova configuração, onde criou-se a oportunidade para que novos departamentos surgissem e foi dada autonomia para que cada setor desenvolvesse suas atribuições de forma eficiente e eficaz (Figura 14), além de mostrar melhora no fluxo de informações, que é um ponto importante para a programação de processos, como foi verificado em Barcelos et al. (2017).

Figura 14 - Redesenho da Estrutura Organizacional - Gestão Atual

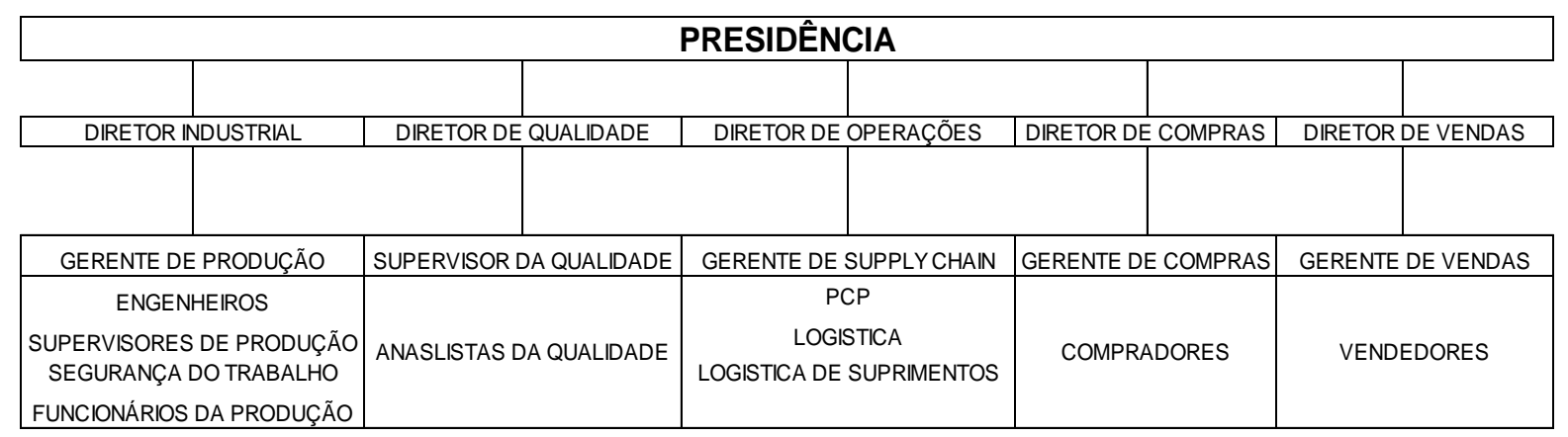

Fonte: Própria autoria

Nessa nova estruturação, foi possível extrair o melhor de cada departamento e promover o trabalho em equipe, pois conforme Harrington, Esseling e Nimwegen (1997), o redesenho de processos também pode ser entendido como a soma dos esforços dos gestores para refinar um processo atual. Ainda, de acordo com Hammer, Champy e Korytowski (1994), a reestruturação busca melhorias nos indicadores da Organização, seja em custos, qualidade, serviços ou velocidade; similarmente ao observado na companhia após a nova estruturação organizacional. 
Isso foi possível, pois na reestruturação passou a ser obrigatório que as propostas básicas e os objetivos traçados chegasssem no nível operacional, com o intuito de que todos os colaboradores da empresa entendessem e acreditassem no trabalho que estava sendo iniciado. O conceito, apesar de aparentar-se simples, causa uma mudança cultural na organização, visto que integra todos os setores desde o início até o fim de cada processo.

As propostas iniciais da mudança organizacional foi a priorização do atendimento dos clientes e o planejamento estratégico focado em alcançar os objetivos propostos no presente trabalho. As informações de atendimento, prioridades e produtividade começaram a ser divulgadas diariamente e os supervisores eram responsáveis por repassar essas informações à operação. Inicialmente os colaboradores foram impactados pela pequena parcela que não era possível ser atendida e, então, despertou maior interesse em entender o porquê isso acontecia. $\mathrm{A}$ partir disso, a parceria entre os operadores com os demais departamentos do processo produtivo e, principalmente, com o envolvimento direto dos líderes de cada departamento desenvolveu maior contribuição para alcançar as metas traçadas pela organização. Além de que, cada conquista passou a ser comemorada provocando maior motivação para realizar suas determinadas tarefas.

Os resultados alcançados não foram limitados somente na melhoria do atedimento aos clientes, eles se estenderam também em outros indicadores, como na segurança operacional de cada colaborador, na produtividade e no nível de qualidade das produções reduzindo o número de interdições, o que mostra o grande impacto causado pelo planejamento e controle de produção em uma organização.

\subsection{Programação do PCP durante a gestão anterior}

A princípio, a programação do fluxograma do PCP era fundamentada somente nos pedidos em carteira, ou seja, somente naqueles pedidos que já estavam confirmados pelos clientes (Figura 15). Não havia uma prévia avaliação dos cenários anteriores e futuros para estudar a quantidade aproximada de pedidos no determinado período e, assim, prevenir ao máximo o estoque de produtos a ser vendidos para os clientes que pedem sem a antecedência para realizar a programação. Esse método 
causava desordens durante a produção, gerando acúmulos e/ou atrasos nas entregas dos produtos.

Figura 15 - Fluxo de Programação - Gestão Anterior

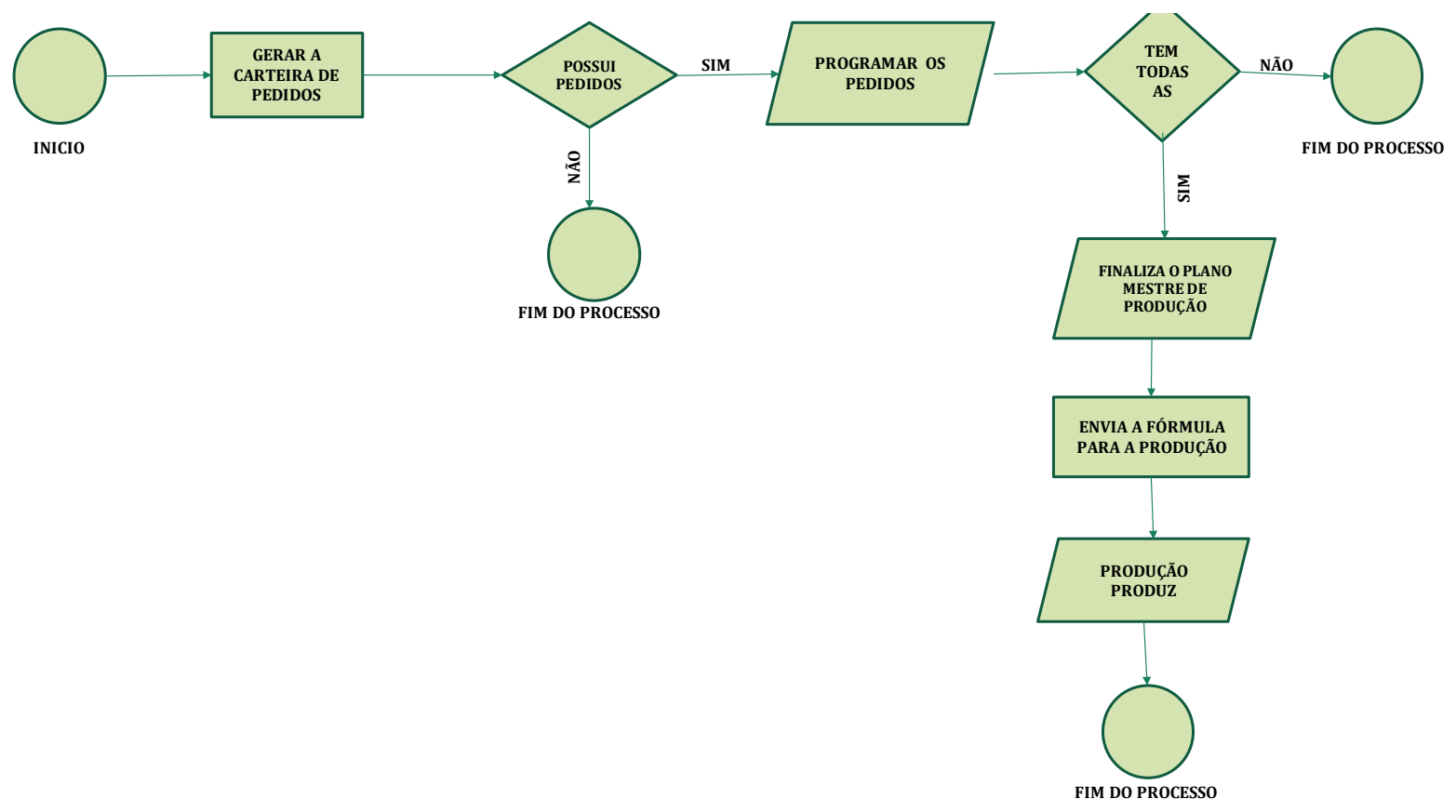

Fonte: Própria autoria.

O conceito usado para planejar e programar a produção pode ser considerado falho, visto que sua eficiência deixa a desejar pela falta do produto no momento da necessidade do cliente que não confirmou o pedido antecipadamente, o que pode fazer com que a empresa perca-o pela sua insatisfação com o produto faltante. Isso mostra a necessidade de um gerenciamento de demanda, como verificado por De Oliveira, De Almeida Dourado e Mello (2017), que provaram que esta é uma ferramenta fundamental que, combinada com a estratégia da organização, com as capacidades de produção e com as necessidades do cliente, assumiu um papel central no processo de planejamento, para a tomada das decisões financeiras, comerciais e operacionais.

\subsection{Redesenho da programação do PCP}

5.4.1. Classificação das atividades realizadas pelo PCP 
No contexto estratégico para todo o processo produtivo, foi necessário rever todas as atividades do PCP, listá-las e numerá-las de acordo com o grau de prioridade de cada uma delas, buscando sempre melhorias e métodos que agilizem ou encurtem o processo, sem que ocorram perdas na sua eficiência (Quadro 1).

Quadro 1 - Atividades realizadas pelo PCP

\begin{tabular}{|c|l|}
\hline $\begin{array}{c}\text { No DA } \\
\text { ATIVIDADE }\end{array}$ & \multicolumn{1}{c|}{ ATIVIDADES DO PCP } \\
\hline 1 & Programar as rotas de produção \\
\hline 2 & Verificar a disponibilidade das Matérias-primas \\
\hline 3 & $\begin{array}{l}\text { Averiguar a possibilidade de trocar ingredientes mediante possíveis } \\
\text { faltas }\end{array}$ \\
\hline 4 & Analisar a disponibilidade de armazenagem \\
\hline 5 & Controlar a Produção \\
\hline 6 & Efetuar os apontamentos de produção \\
\hline 7 & Governar o nível de atendimento da unidade (OTIF) \\
\hline 8 & Coordenar os Inventários mensais \\
\hline 9 & Amparar as operações de armazenagem externa \\
\hline 10 & Aferir as solicitações de antecipação de cargas \\
\hline 11 & Auxiliar no controle de produtos obsoletos \\
\hline 12 & $\begin{array}{l}\text { Ajudar no processo de produtos interditados direcionados para } \\
\text { reprocesso }\end{array}$ \\
\hline 13 & Reger o controle de sackoff \\
\hline
\end{tabular}

Fonte: Própria autoria.

As atividades realizadas pelo PCP foram classificadas de acordo com seus respectivos níveis de impacto e probabilidade (Quadro 2), consideradas de acordo com IFAC (1999) que os classifica da seguinte maneira:

Quanto ao impacto: a) Alto - provoca um impacto significativo nas metas estratégicas de uma organização; b) Médio - provoca impacto moderado nas metas estratégicas de uma organização e, c) Baixo - provoca um impacto mínimo nas metas estratégicas de uma organização.

Quanto a probabilidade: a) Alta (provável) - possui mais de $25 \%$ de chance de ocorrer ou pode ocorrer entre o período de um ano; b) Média (possível) - possui entre 
2 a $25 \%$ de chance de ocorrer ou pode ocorrer entre o período de dez anos e, c) Baixa (remoto) - possui menos de $2 \%$ de chance de ocorrer ou não deve ocorrer entre um período de dez anos.

Quadro 2 - Classificação das atividades realizadas pelo PCP de acordo com seu grau de impacto e probabilidade

\begin{tabular}{|c|l|c|c|}
\hline $\begin{array}{c}\text { NNo DA } \\
\text { ATIVIDADE }\end{array}$ & ATIVIDADES DO PCP & IMPACTO & PROBABILIDADE \\
\hline 1 & Programar as rotas de produção & Alta & Alta \\
\hline 2 & $\begin{array}{l}\text { Verificar a disponibilidade das Matérias- } \\
\text { primas }\end{array}$ & Alta & Alta \\
\hline 3 & $\begin{array}{l}\text { Averiguar a possibilidade de trocar } \\
\text { ingredientes mediante possíveis faltas }\end{array}$ & Alta & Alta \\
\hline 4 & Analisar a disponibilidade de armazenagem & Alta & Alta \\
\hline 5 & Controlar a Produção & Alta & Alta \\
\hline 6 & Efetuar os apontamentos de produção & Alta & Alta \\
\hline 7 & $\begin{array}{l}\text { Governar o nível de atendimento da unidade } \\
\text { (OTIF) }\end{array}$ & Alta & Alta \\
\hline 8 & Coordenar os Inventários mensais & Alta & Média \\
\hline 9 & $\begin{array}{l}\text { Amparar as operações de armazenagem } \\
\text { externa }\end{array}$ & Média & Baixa \\
\hline 10 & $\begin{array}{l}\text { Aferir as solicitações de antecipação de } \\
\text { cargas }\end{array}$ & Média & Alta \\
\hline 11 & Auxiliar no controle de produtos obsoletos & Média & Média \\
\hline 12 & $\begin{array}{l}\text { Ajudar no processo de produtos interditados } \\
\text { e direcionados para reprocesso }\end{array}$ & Baixa & Baixa \\
\hline 13 & Reger o controle de sackoff & Baixa & Média \\
\hline
\end{tabular}

Fonte: Própria autoria

Como forma de exemplificação do método de classificação de riscos das atividades, pode-se considerar que à atividade número 2 (verificar a disponibilidade de matérias primas) foi atribuído alto índice de impacto e probabilidade, pois ela é fundamental para a confecção do produto e deve ocorrer toda vez que surgir nova programação, causando significante impacto nos objetivos estratégicos da empresa.

Em contrapartida, a atividade número 12 (ajudar no processo de produtos interditados direcionados para reprocesso), foi classificada com baixo índice, pois deve ocorrer em mínimas vezes e, quando ocorre, possui pouca influência nas metas estratégicas da empresa. 
Com isso, foi possível inserir todas as atividades listadas acima (Quadro2) na matriz de priorização e visualizar de maneira explícita aquelas que são de análise prioritária, contidas na área vermelha do gráfico (Figura 16).

Figura 16 - Matriz de priorização das atividades realizadas pelo PCP

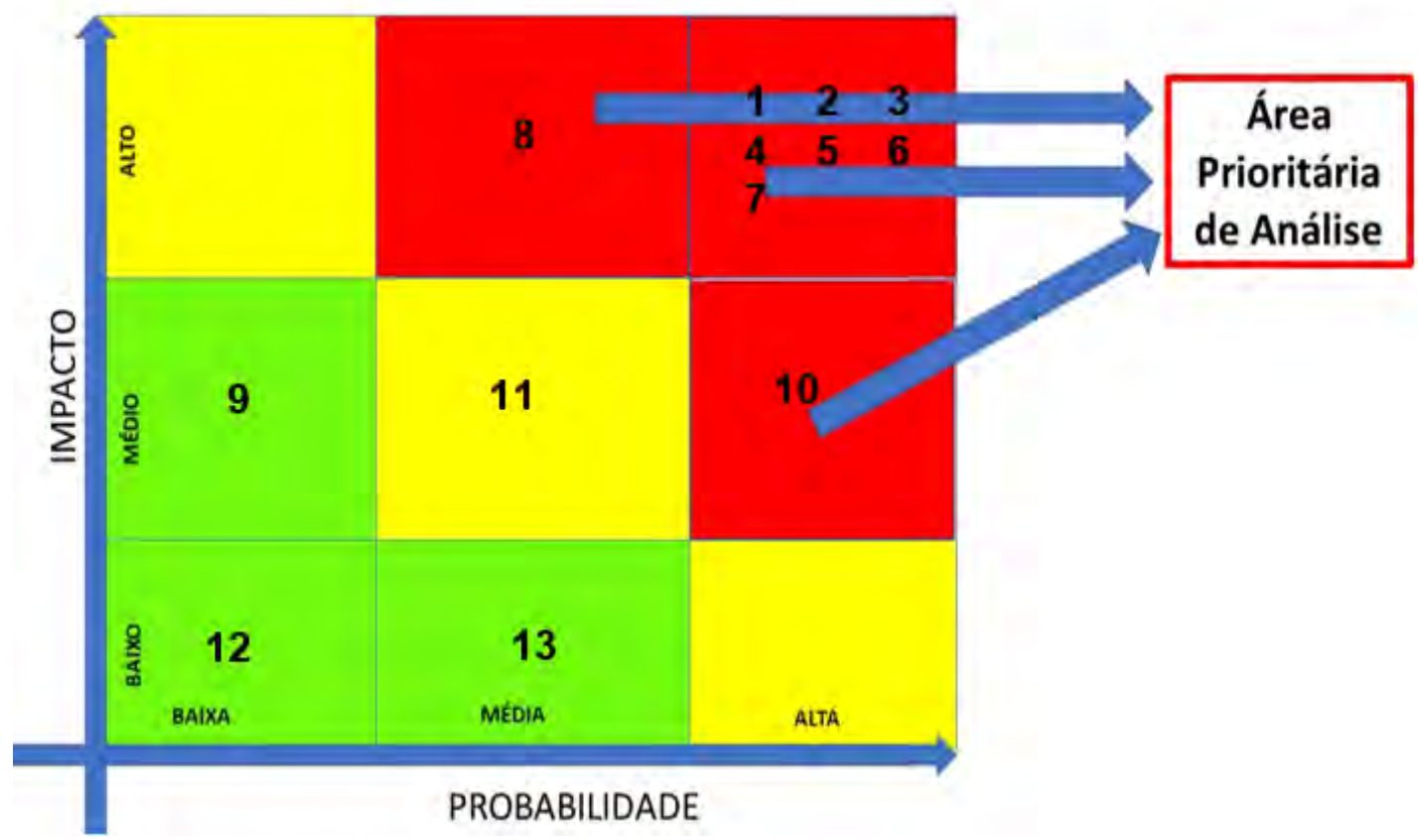

Fonte: Adaptado de INTERNATIONAL FEDERATION OF ACCOUNTANTS - IFAC. Enhancing sharehold wealth by better managing business risk. New York: FMAC,1999.

Portanto, de acordo com a análise de percepção do pesquisador, as atividades que precisam ser priorizadas para posterior avaliação e redesenhos são:

1) Programar as rotas de produção;

2) Verificar a disponibilidade das Matérias-Primas;

3) Averiguar a possibilidade de trocar ingredientes mediante possíveis faltas;

4) Analisar a disponibilidade de armazenagem;

5) Controlar a produção;

6) Efetuar os apontamentos de produção;

7) Governar o nível de atendimento da unidade (OTIF). 


\subsubsection{Ferramentas utilizadas pela empresa na gestão anterior}

Para efetuar o redesenho do novo fluxo de trabalho do PCP, foi necessário efetuar uma análise metódica de cada atividade e, consequentemente, qual sua efetividade, verificando se as ferramentas que a empresa possui são suficientes, se requerem melhorias ou até mesmo se carecem de novas ferramentas.

No primeiro momento, verificou-se qual o software que a empresa possuía. Constatou-se, então, que a mesma fazia o uso de um sistema integrado MRP/ERP bem eficiente e que armazena todos os dados que forem imputados ou computados nele, ou seja, pelo software é possível verificar desde a entrada de pedidos, programação da produção, explosão de matérias-primas, produção e venda, até as informações do pós venda; o observado vai de encontro com Bianchini et al. (2017) que mostraram que o uso do sistema MRP atendeu satisfatoriamente a demanda prevista e pode oferecer suporte para o planejamento de produção. A ferramenta, também foi eficiente nas funções de armazenagem de cadastros de todos os clientes e funcionários, de contas a pagar e a receber, assim como dos custos gerais da planta ou dos produtos.

O sistema funciona de maneira bem dinâmica e os relatórios são de fácil interpretação. Basta saber o seu propósito e manejar os relatórios de forma com que se facilite ou ajude a chegar no objetivo proposto.

Posteriormente, analisou-se as atividades principais que fazem parte da rotina diária do PCP e foi possível listá-las da seguinte forma:

a) Programar e controlar a produção;

b) Gerenciar os estoques;

c) Prever a demanda.

Contudo, pode-se afirmar que para se efetuar cada atividade listada acima, o processo é muito mais complexo.

Para se programar a produção por meio do método Just in Time (JIT), que consiste em produzir o bem ou o serviço no momento em que é necessário, é preciso, 
primeiramente, extrair do software um relatório em que conste todos os pedidos confirmados que foram direcionados para produção na empresa, o qual é chamado de carteira de pedidos.

Posteriormente, é preciso efetuar a programação de cada produto no plano mestre de produção e confirmar. O próximo passo é efetuar uma explosão, ou seja, computar todos os produtos que foram programados e verificar quais as matériasprimas (MP) e suas respectivas quantidades necessárias para executar o plano de produção. Neste processo, imediatamente, é enviado um e-mail para todo o departamento responsável pelas compras dessas MP, informando o saldo em estoque de cada uma, o volume que será consumido e o saldo que restará em estoque para as produções futuras. Em caso da falta de alguma MP, o departamento responsável retorna o e-mail enviado com a previsão da chegada do ingrediente faltante. Estando tudo de acordo com as MP, o produto é enviado para a produção em forma de receita e contendo todas as informações para que o mesmo seja produzido. Após o final da produção o supervisor de produção precisa realizar a checagem do produto e finalizar a produção para que este possa ser enviado ao estoque.

Apesar do processo aparentar ser simples, não são todos os clientes que fazem seus pedidos com a devida antecedência, ou seja, se o pedido não está no sistema, não é possível para o PCP realizar sua produção. Visto isso, é necessário realizar as reestruturações nesta fase para que esses pedidos sejam atendidos.

5.4.3. Ferramentas utilizadas para realizar o redesenho da programação do PCP

Pelo software, é possível buscar todos os produtos e suas quantidades em um determinado período, portanto pode-se obter um histórico mensal da quantidade de cada produto que foi vendida neste determinado período. Outra referência é a previsão de vendas, realizada pelo departamento comercial, pois através dela se faz possível antecipar e efetuar um planejamento mais preciso sobre qual produto deve ser produzido em determinada oportunidade. No entanto, esse processo também não é tão simples, sendo que dependerá da capacidade de armazenagem ou do espaço disponível para produzi-lo. 
Visto isso, pode-se afirmar que tão importante quanto a programação e o controle da produção, necessita-se efetuar e gerenciar a estocagem para evitar faltas ou excessos, para que desta forma seja possível realizar uma análise sobre o que produzir, quanto produzir e quando produzir.

Para gerenciar o estoque é necessário realizar uma análise comum por meio da classificação ABC, segundo Viana (2000), uma importante ferramenta para gerir os estoques e, que de acordo com De Aguiar, De Oliveira e Cervi (2017) auxilia os administradores na otimização das tomadas de decisões, possibilitando identificar qual tratamento deverá ser dado a cada classe de itens, de acordo com o critério selecionado. Graças ao seu grande portifólio de produtos, a empresa possui uma boa capacidade de armazenagem, ainda que seja necessário verificar diariamente o nível de estocagem classificado por famílias de produtos antes de efetuar a programação, por meio de uma ferramenta denominada velocímetro (Figura 17).

Figura 17 - Velocímetro de estoque

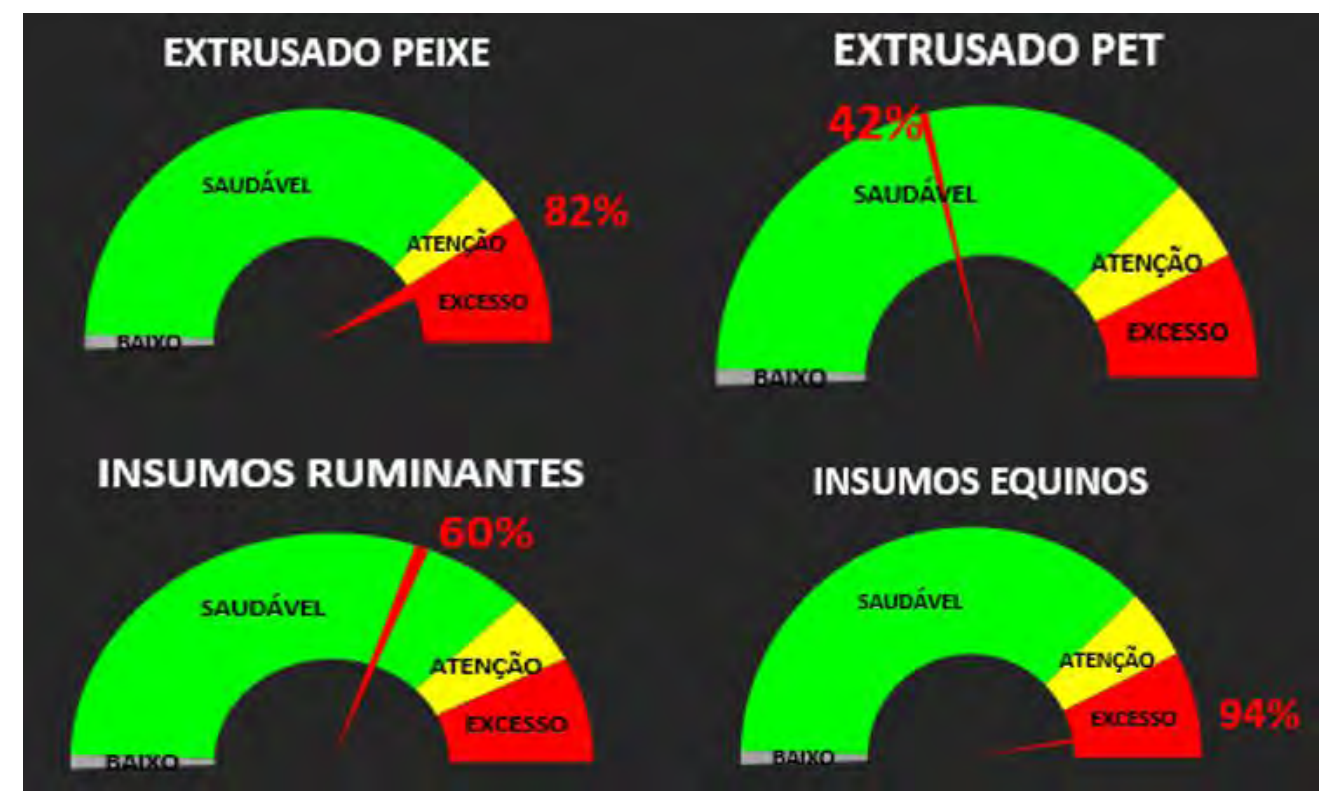

Fonte: Acervo da empresa

No velocímetro é possível verificar três cores: verde, amarelo e vermelho. Quando o velocímetro encontra-se na cor verde, significa que sua capacidade de armazenagem está saudável e apresenta até $75 \%$ de ocupação. Na cor amarela, o velocímetro indica ponto de atenção e representa de 76 a 85\% da capacidade de armazenagem de cada família. Já o vermelho, mostra perigo ou que a armazenagem está próxima da lotação máxima, representando de 86 a 100\% de ocupação. 
Outra ferramenta para gestão de estoques é o WMS (Warehouse Management System) que, de acordo com Banzato (2016), também pode ser explicado como um modelo de gestão de armazém que otimiza as atividades operacionais, como o fluxo de materiais, e as atividades administrativas, como o fluxo de informações, dentro do processo de armazenagem, atuando sobre o recebimento, a estocagem, a separação de pedidos, a expedição e o inventário.

Apesar de esforços para implementá-la na Companhia do presente estudo, não houve resultados satisfatórios, pois tratavam-se de dois softwares que trabalhavam simultaneamente (software da própria Companhia versus software do WMS) e chocaram-se em algumas informações, o que acarretou impactos negativos no atendimento aos clientes. Essa inconsistência de sistemas deu-se pois o software do WMS realiza a leitura dos produtos em estoque de maneira verticalizada, que trata-se de produtos armazenados em prateleiras endereçadas. No entanto, a empresa em questão possui armazenagem de estoque tanto verticalizada como em sistema blocado, que são paletes empilhados um sobre outro, colocando-se o primeiro palete diretamente sobre o piso. Devido a isso, tornou-se inviável a permanência do sistema WMS, sendo necessário um novo estudo para adaptação à referida empresa e sua futura aplicabilidade.

Visto isso, a averiguação pelo departamento de PCP dos sistemas e ferramentas empregados na organização mostraram-se de suma importância para poder criar o plano mestre de produção da empresa, que é a base do fluxograma de produção.

\subsubsection{Redesenho do fluxograma de programação do PCP}

Após a verificação das principais atividades do PCP e das ferramentas disponíveis para auxílio de trabalho, criou-se a necessidade de rever a forma com que essas ferramentas eram utilizadas e como seria viável aprimorar os processos, de maneira a serem mais eficientes e assertivos. Assim, com base na literatura levantada e conjuntamente com a experiência profissional na área do autor, foi possível realizar a proposta de redesenho do processo (Figura 18). 
Figura 18 - Redesenho do Fluxograma de Programação - Gestão Atual

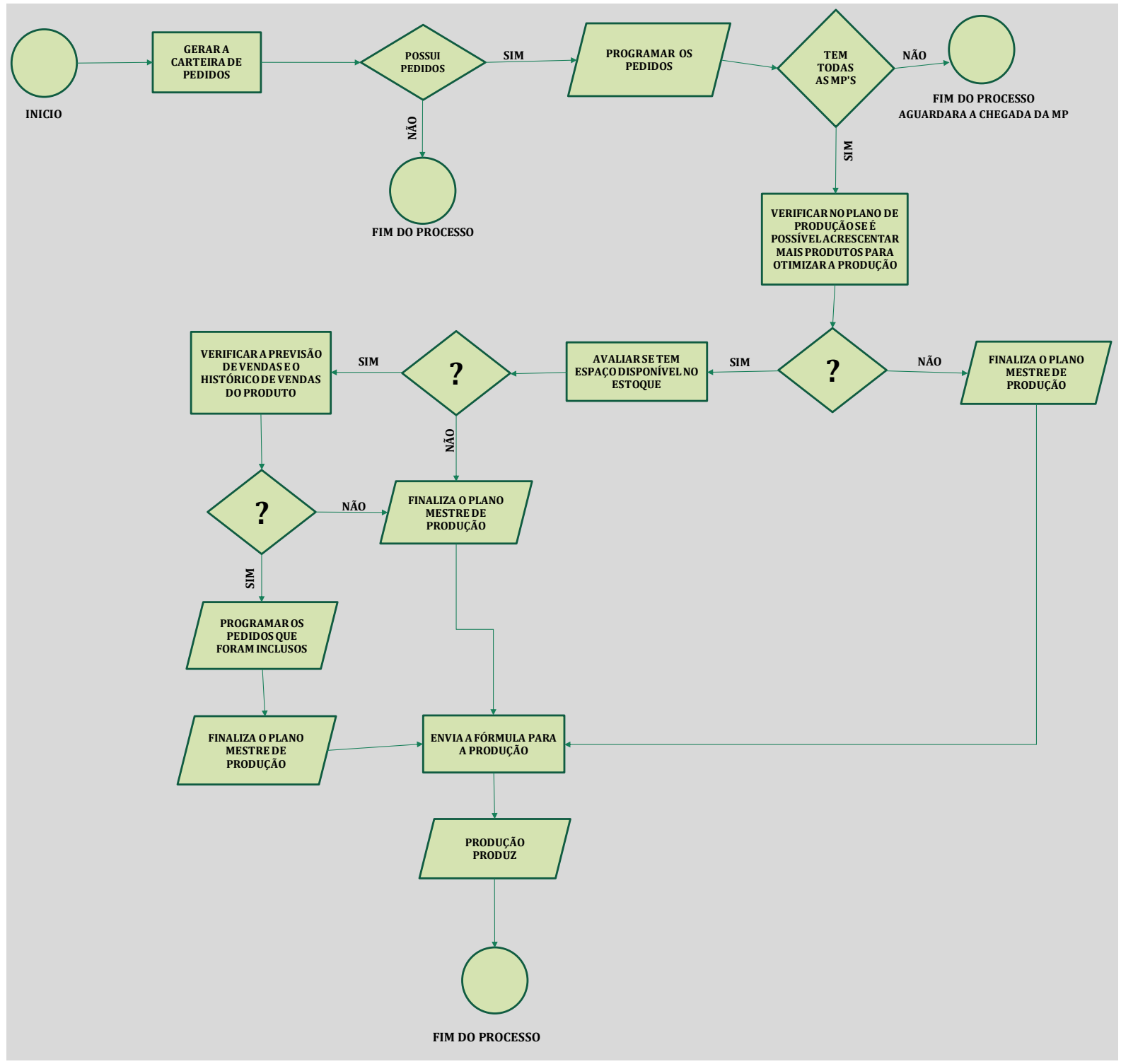

Fonte: Própria autoria

Como forma de elucidação do fluxograma apresentado (Figura 18), no primeiro passo do processo (Figura 19) há a necessidade de se gerar diretamente no software um relatório denominado "disponibilidade", o qual é utilizado pela Companhia no ramo de nutrição animal. Este relatório é uma análise do estoque atual da empresa perante a carteira de pedidos que possui para ser entregue em 0 (zero) horas, 24 horas, 48 horas, 72 horas e até acima de 72 horas. $O$ relatório gerado automaticamente requer a inserção de mais cinco colunas com fórmulas básicas de subtração para avaliar até 
que momento o estoque suportará ou qual a necessidade real de programação de determinado produto. Feito isso, é necessário analisar o estoque e prever em que data ele irá se esgotar, a fim de se produzir um novo lote antes de ser consumido completamente. Também é necessário verificar qual a disponibilidade de espaço para armazenagem, se será possível comportar toda a quantidade que possui na carteira de pedidos ou se será necessário estratificar em dois ou mais lotes para atender todos os requisitos, e então, programar os respectivos produtos e suas quantidades.

Ainda no primeiro passo do redesenho do fluxograma (Figura 19), após finalizar a programação de todas as rotas, é preciso gerar uma "explosão", que consiste em criar outro relatório com todas as matérias-primas que serão necessárias para a produção daqueles produtos. Neste relatório será considerado o estoque atual das matérias primas, a quantidade necessária para cada ingrediente e, evidentemente, se o estoque é suficiente ou não para o determinado plano de produção. Posteriormente, o PCP sequenciará a ordem de produção dos diferentes produtos, respeitando as ordens de qualidade e, em caso de a demanda não ser suficiente, partirá para o segundo passo da programação.

Figura 19 - Primeira etapa do redesenho do fluxograma de programação

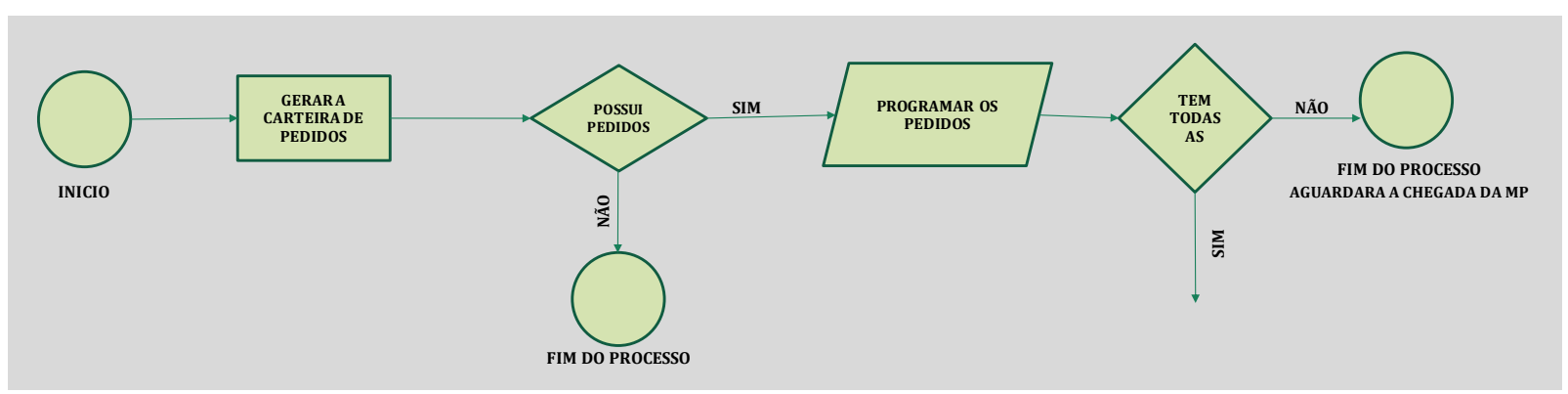

Fonte: Própria autoria.

Na segunda etapa do redesenho do fluxograma de produção (Figura 20), será necessário fazer mais uma análise com o objetivo de completar a programação de forma a não deixar as máquinas ociosas. Nesta análise verifica-se a disponibilidade de espaço para armazenagem e a previsão de vendas, além de considerar o histórico de vendas e a acuracidade das previsões para auxiliar no processo de decisão sobre a quantidade e os produtos que irão ser programados para completar o fluxo de produção. A partir disso, planeja-se os itens selecionados, faz-se a "explosão" de matérias primas e sequencia-os na grade de produção. 
Figura 20 - Segunda etapa do redesenho do fluxograma de programação

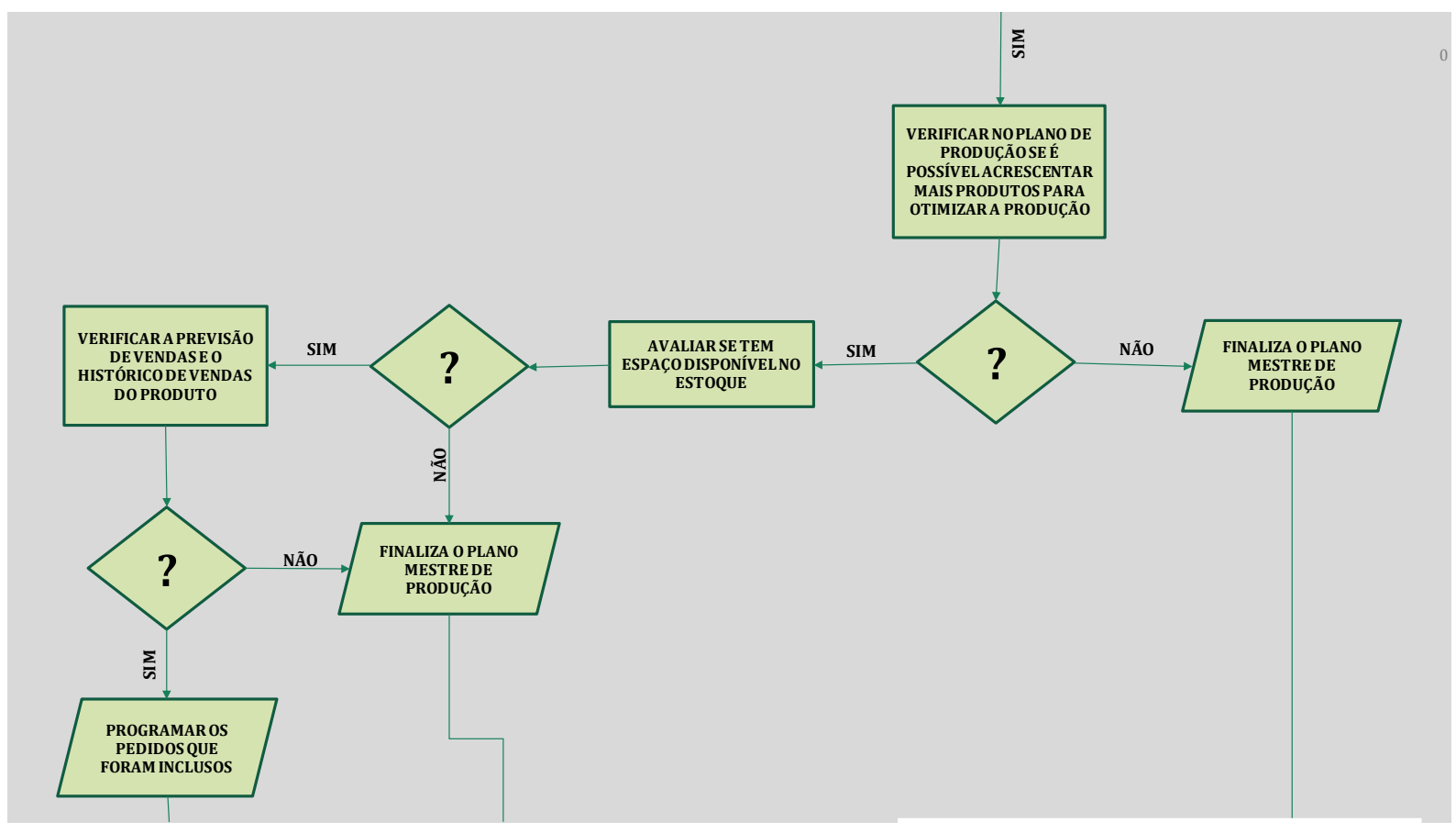

Fonte: Própria autoria

No terceiro e último processo do redesenho do fluxograma de programação (Figura 21), é necessário encerrar o plano de produção, enviar as fórmulas dos produtos automaticamente para a produção através do software e acompanhar a finalização das produções na fábrica. 
Figura 21 - Terceira etapa do redesenho do fluxograma de programação

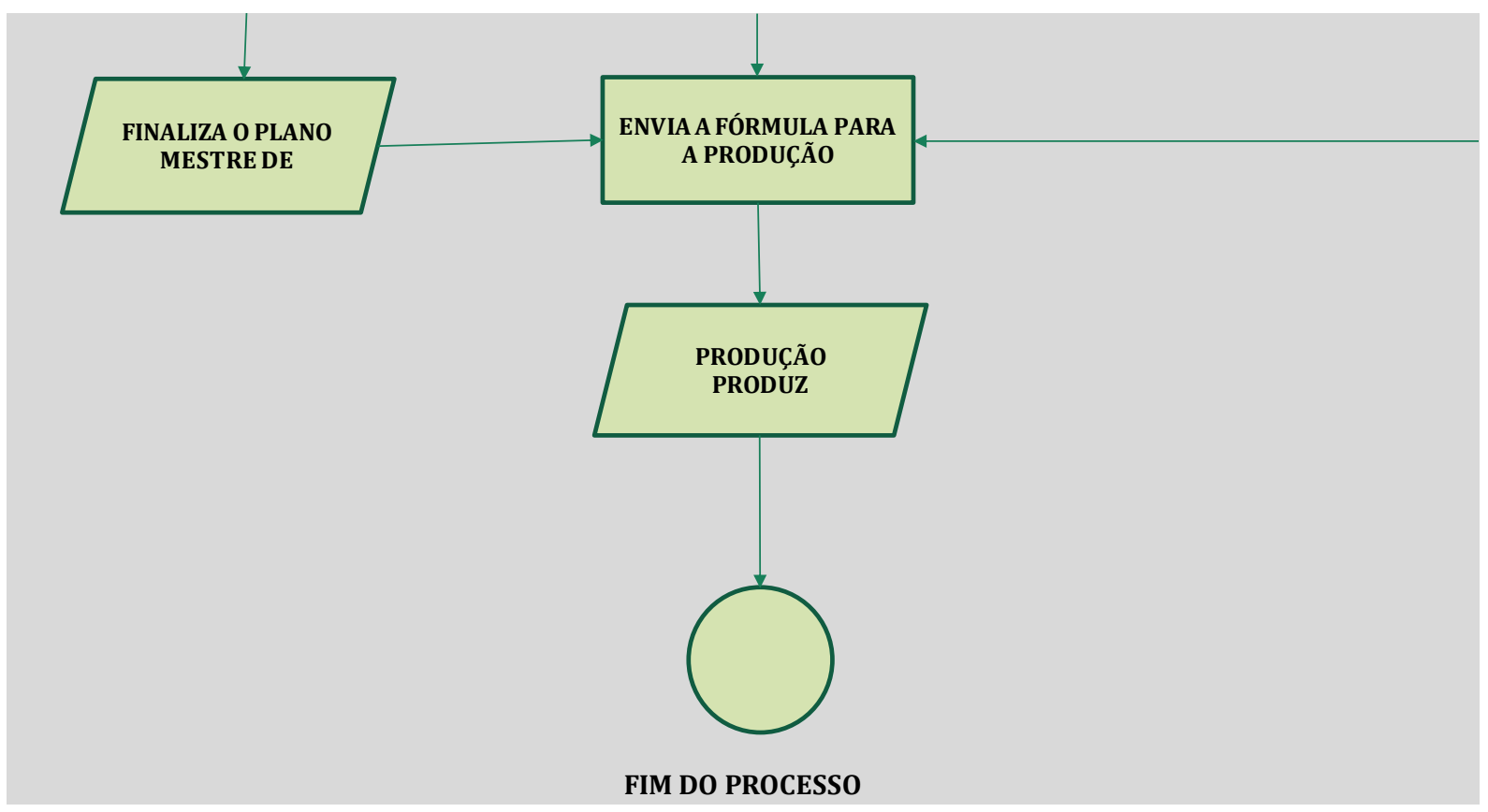

Fonte: Própria autoria

\subsection{On Time In Full (OTIF)}

Em consonância com as modificações propostas, foi possível medir por meio de um Indicador-Chave de Desempenho ou Key Performance Indicator (KPI) denominado de On Time In Full (OTIF), a melhora exposta em números para o sucesso das modificações (Figura 22).

Figura 22 - OTIF da Empresa estudada de novembro de 2018 a abril de 2020

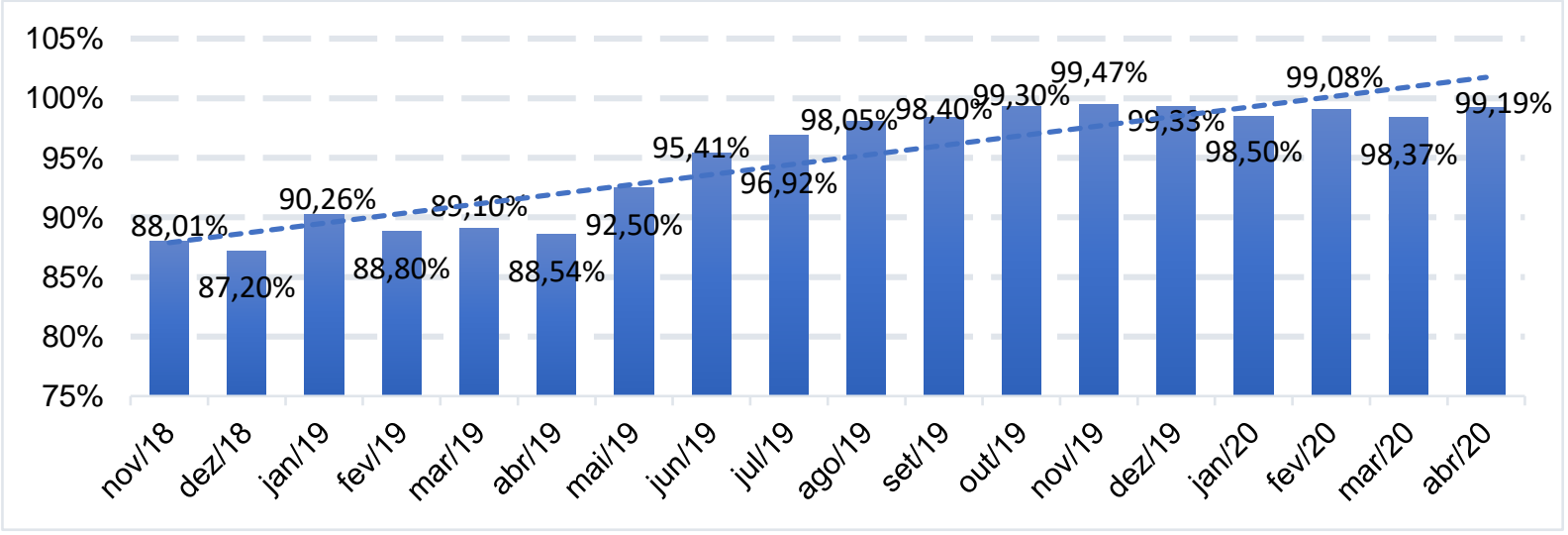

Fonte: Acervo da empresa 
Segundo Silva e Silva (2019), KPI pode ser explicado como uma ferramenta de gestão usada para medir e nivelar o desempenho e o sucesso de uma organização ou de um determinado processo. Já o OTIF é utilizado para acompanhar a qualidade das entregas dos produtos como um indicador de desempenho com objetivo de aumentar a satisfação dos clientes em relação ao serviço prestado pela empresa, através da entrega do produto dentro do prazo e do atendimento de suas expectativas, o que contribui para a maximização da oportunidade de fidelização destas pessoas.

A expressão On Time associa-se ao prazo, data e horário, e ao local que foram combinados com o cliente previamente, e a expressão In Full, refere-se aos produtos serem entregues dentro das especificações passadas ao cliente no momento da compra, como dimensões, quantidade, qualidade, integridade, entre outras (OLIVEIRA; ARAÚJO, 2009).

No referente estudo, pode-se observar um aumento no OTIF entre os meses de novembro de 2018 a abril de 2020, mostrando a melhora no desempenho da empresa, a partir da contribuição gerada pela implementação do redesenho da programação do fluxo do PCP na gestão atual. 


\section{CONSIDERAÇÕES FINAIS}

O presente trabalho buscou o melhor método a ser seguido e as ferramentas ideais a serem usadas para auxiliar no processo de planejamento no departamento de PCP de uma empresa na busca de aumentar seu desempenho operacional. Por meio de pesquisa bibliográfica, levantamentos de dados da Companhia e experiência profissional do autor, foi possível comparar o fluxograma da programação do PCP na gestão anterior com o redesenho proposto pelo autor na gestão atual.

$\mathrm{Na}$ gestão anterior, a programação era baseada somente nos pedidos em carteira, sem uma prévia análise ou avaliação dos cenários anteriores ou futuros, gerando acúmulos ou atrasos nas entregas dos produtos devido a falha na previsão ou na programação pela falta do produto no momento da necessidade do cliente.

Na gestão atual, o PCP precisa atuar de forma estratégica e eficaz, obtendo a junção de ferramentas e relatórios disponíveis pela empresa. Desta forma, o PCP precisa analisar os históricos de vendas, principalmente do mês anterior e o do mesmo período no ano antecedente, posteriormente analisar as previsões de vendas passada pelo departamento comercial e verificar se os volumes estão de acordo ou serão ideais para o período.

Por fim, busca-se efetuar a programação, considerando a carteira de pedidos, que possuem os pedidos já confirmados. Antes de finalizar o plano mestre de produção, considera-se a capacidade de estocagem e analisa-se por meio da previsão e do histórico de vendas, se tem algum produto de alto giro que será possível acrescentar ou completar a programação; desse modo, é viável otimizar e antecipar produções, mantendo a organização do estoque e satisfazendo os clientes, que são considerados peças-chave para o sucesso da Companhia.

Contudo, pode-se inferir que o departamento de PCP possui um papel fundamental na gestão estratégica da referida empresa estudada, pois é ele o responsável pelas programações essenciais que melhoram a eficiência e alavancam a organização para o sucesso no mercado de nutrição animal.

Neste contexto, é importante destacar os resultados obtidos na pesquisa qualitativa, onde analisou-se o impacto do redesenho do PCP no âmbito da empresa, 
nas mais diferentes facetas: estratégica, organizacional e na integração das ferramentas propostas. Sob o panorama geral, apreendido pela metodologia da pesquisa e obtido através da revisão da literatura e com base nos dados primários colhidos no próprio acervo e recursos humanos da empresa, ressalta-se a relevância e a eficácia da análise de gerenciamento de processos de negócios para legitimar os resultados obtidos qualitativamente.

O PCP está associado diretamente a todos os processos, desde o momento da chegada da matéria prima até a entrega do produto para o cliente. Se o PCP falhar, toda a empresa poderá sofrer os resultados, pois não será possível conquistar um cliente satisfeito e, consequentemente, fiel. Além disso, também pode-se destacar a posição da gestão, pois por meio desta é possível alcançar resultados positivos quando bem realizada.

Neste sentido, confirma-se a hipótese inicialmente levantada, na qual existia espaço para a consecução de uma proposta de redesenho, baseada na análise de processos de negócios, a fim de que o Departamento de Planejamento e Controle da Produção (PCP) melhorasse seu desempenho e seu papel fundamental na gestão estratégica da empresa de nutrição animal.

Então, pode-se afirmar que o PCP precisa ser o eixo operacional dentro de uma organização e que, em paralelo, necessita-se uma gestão focada para oferecer suporte para que a empresa consiga chegar a níveis satisfatórios na competitividade do mercado.

Pelos resultados apresentados, fica patente o impacto positivo do trabalho realizado no Programa de Pós-Graduação em Gestão e Inovação na Indústria Animal (GIIA) da Faculdade de Zootecnia e Engenharia de Alimentos (FZEA) da Universidade de São Paulo (USP), no âmbito do Mestrado Profissional, para a empresa e para a qualificação do pesquisador. 


\section{REFERÊNCIAS}

ALMEIDA, H. Nutrição animal: Demanda globar por carnes explode e estimula avanço dos ingredientes. Revista Química e Derivados, São Paulo, ano LV, n.610, 2020. Disponível em: <https://sindiracoes.org.br/wpcontent/uploads/2020/03/Qu\%C3\%ADmicaDerivados_Nutri\%C3\%A7\%C3\%A30 Animal_20Mar2020.pdf>. Acesso em: 12/04/2020

ANDRIGUETTO, J. M.; PERLY, L. Nutrição animal: bases e fundamentos. NBL Editora, 1994.

ASSOCIAÇÃO BRASILEIRA DE NORMAS TÉCNICAS - ABNT. NBR ISO/IEC 27005: Tecnologia da Informação - Técnicas de Segurança - Gestão de riscos de segurança da informação. 2. ed. Rio de Janeiro, RJ: ABNT, 2011.

ASSOCIATION OF BUSINESS PROCESS MANAGEMENT PROFESSIONALS ABPMP. Guia para o gerenciamento para processos de negócio. São Paulo: ABPMP, 2013.

BALDAM, R. et al. Gerenciamento de processos de negócios: BPM - Business Process Management. 2. ed. São Paulo: Érica, 2009.

BANZATO, E. Tecnologia da informação aplicada à logística. São Paulo: IMAM, 2016. ISBN 8589824594.

BANZATO, E. et al. Atualidades na armazenagem. São Paulo: IMAM, 2003.

BARCELOS, R. L. et al. Sistema de informações para processo de planejamento e controle da produção: estudo de caso aplicado a uma indústria de confecção. Exacta, v. 15, n. 4, p. 155-165, 2017.

BEDIN, A. A.; GASPAROTTO, A. M. S. Tecnologia industrial e melhoria contínua no chão de fábrica. Revista Interface Tecnológica, v. 15, n. 2, p. 470-479, 2018.

BESERRA, J. P. S.; ESTENDER, A. C. Planejamento programação e controle de produção: Sistema Just In Time. Revista da Universidade Vale do Rio Verde, v. 14, n. 2, p. 887-904, 2016.

BESSANT, J. et al. Rediscovering continuous improvement. Technovation, v. 14, n. 1, p. 17-29, 1994. ISSN 0166-4972. 
BIANCHINI, J. et al. Análise de planejamento e controle da produção baseada na simulação de um processo produtivo utilizando um modelo híbrido de MRP e Kanban. Journal of Lean Systems, v. 3, n. 1, p. 66-86, 2017.

CAFFYN, S. Development of a continuous improvement self-assessment tool. International Journal of Operations \& Production Management, v. 19, n. 11, p. 11381153, 1999. ISSN 0144-3577.

CARINA, L.; ATTADIA, L.; MARTINS, R. A. Medição de desempenho como base para evolução da melhoria contínua. Revista Produção, v. 13, n. 2, p. 33, 2003.

CORRÊA, H. L.; CORRÊA, C. A. Administração de Produção E Operações: Manufatura E Serviços: Uma Abordagem Estratégica. Editora Atlas SA, 2000. ISBN 8522479186.

CORRÊA, H. L. et al. Planejamento, programação e controle da produção. São Paulo: Atlas, v. 1, 2001

CORRÊA, H. L.; GIANESI, I. G. N.; CAON, M. Planejamento, programação e controle da produção: MRP II / ERP: conceitos, uso e implantação: base para SAP, Oracle Applications e outros softwares integrados de gestão. - $5^{\text {a }}$ Ed.- $2^{\text {a }}$ reimpr. São Paulo: Atlas, 2008.

COSTA, F.; DE SANTANA, L. T.; FERNANDES, S. Gestão de estoque: estudo de caso sobre previsão de demanda em uma microempresa fabricante de materiais esportivos. Refas-Revista Fatec Zona Sul, v. 3, n. 3, p. 16-30, 2017.

COSTA, I. S. A.; DOS SANTOS GURGEL, J.; DA COSTA SOUZA, A. M. Funções e aplicações das atividades do planejamento e controle da produção em uma indústria de insumos para empresas do setor têxtil do ceará. Revista Gestão em Análise, v. 9, n. 2, p. 159-168, 2020.

DA SILVA COSTA, W. A.; JÚNIOR, J. A. G. Etapas de implementação de WMS: estudo de caso em um varejista moveleiro. Revista GEPROS, v. 4, n. 4, p. 101, 2008. ISSN 1984-2430.

DA SILVA, R. M.; DUARTE, L.; DA SILVA, M. G. Analysis of production planning and control (PPC) through the approach of systems thinking/Análise do planejamento e controle da produção (PPC) através da abordagem do pensamento sistêmico. Brazilian Journal of Development, v. 5, n. 11, p. 24182-24198, 2019. 
DAVENPORT, T. H. Process innovation: reengineering work through information technology. Harvard Business Press, 1993. ISBN 1422160661.

DE AGUIAR, R.; DE OLIVEIRA, P. A.; CERVI, R. G. Utilização da classificação abc para gestão de estoque em uma microempresa. Tekhne e Logos, v. 8, n. 1, p. 212, 2017.

DE OLIVEIRA, E. S.; DE ALMEIDA DOURADO, J. D.; MELLO, J. A. V. B. Aplicação de modelos de previsão de demanda em uma fábrica de embalagens plásticas. Revista da Universidade Vale do Rio Verde, v. 15, n. 2, p. 354-373, 2017.

DOS SANTOS, $M$. et al. Cálculo da previsão de demanda de uma multinacional/Calculation of a multinational's demand forecast. Brazilian Journal of Development, v. 4, n. 6, p. 3035-3052, 2018. ISSN 2525-8761.

GISLON, L. Planejamento e Controle da Produção: Gestão da demanda e estoques. 2012. 29 f. Monografia (Especialização) - Universidade Tecnológica Federal do Paraná, Ponta Grossa, 2012.

HAMMER, M.; CHAMPY, J.; KORYTOWSKI, I. Reengenharia: revolucionando a empresa em função dos clientes, da concorrência e das grandes mudanças da gerência. Campus Rio de Janeiro, 1994. ISBN 857001848

HARRINGTON, H. J.; ESSELING, E. K. C.; NIMWEGEN, H. V. Business process improvement: documentation, analysis, design and management of business process improvement. New York: McGraw Hill, 1997.

HÖTZEL, M. J. Sustentabilidade na agricultura e bem-estar animal: a interface social. Senciência e Bem-estar Animal Expandindo Horizontes, p. 98, 2014.

INTERNATIONAL FEDERATION OF ACCOUNTANTS - IFAC. Enhancing sharehold wealth by better managing business risk. New York: FMAC,1999.

JOSUTTIS, N. M. SOA na Prática: A arte da Modelagem de Sistemas Distribuídos. Alta Books, 2008. ISBN 8576081849.

JUNIOR, M. L. J.; GODINHO FILHO FILHO, M. Planejamento e controle da produção (PCP) na remanufatura: análise estratégica por meio de um estudo teórico. Revista TechnoEng-ISSN 2178-3586, v. 1, 2020. 
KETTINGER, W. J.; TENG, J. T.; GUHA, S. Business process change: a study of methodologies, techniques, and tools. MIS quarterly, p. 55-80, 1997. ISSN 0276-7783.

KIRSCH, D. B.; LEMES, L. R. Caracterização da estrutura da pesquisa cientifica. 2019. (Folheto Academia da Força Aérea/ Divisão de Ensino, 2019).

KOERICH, M. S. et al. Pesquisa-ação: ferramenta metodológica para a pesquisa qualitativa. Revista Eletrônica de Enfermagem, v. 11, n. 3, 1 jun. 2017.

KUMAR, C. K.; SINHA, B. K. Efficiency based production planning and control models. European Journal of Operational Research, v. 117, n. 3, p. 450-469, 1999. ISSN 0377-2217.

LEAL, G. C. L.; COTRIM, S. L.; NARDOTTO, J. Utilização do Método de Custeio ABC como Instrumento de Gestão em uma Lanchonete de Pequeno Porte. Revista da Micro e Pequena Empresa, Campo Limpo Paulista, v.10, n.1, p. 80 - 91, 2016.

LONGARAY, A. A. et al. Propostas de redesenho de processos e o papel das equipes organizacionais: uma análise da produção científica à luz da bibliometria. Sistemas \& Gestão, v. 13, n. 2, p. 246-254, 2018

MONTOR, B. R.; BERTACI, M. J. Planejamento e controle de produção. Revista Interface Tecnológica, v. 17, n. 1, p. 578-589, 2020.

MOREIRA, D. A. Administração da Produção e Operações. $2^{a}$ ed. São Paulo: Pioneira, 2001.

MORENO, V.; SANTOS, L. H. A. Gestão do conhecimento e redesenho de processos de negócio: proposta de uma metodologia integrada. Perspectivas em Ciência da Informação, v. 17, n. 1, p. 203-230, 2012.

MÜLLER, C. J. Modelo de gestão integrando planejamento estratégico, sistemas de avaliação de desempenho e gerenciamento processos (MEIO - Modelo de Estratégia, Indicadores e Operações). 2003. 292 f. Tese (Doutorado) - Universidade Federal do Rio Grande do Sul, Porto Alegre, 2003.

OLIVEIRA, S. B. et al. Gestão por Processos: fundamentos, técnicas e modelos de implementação. Rio de Janeiro: Qualitymark, 2006. 
OLIVEIRA, R. R. D.; ARAÚJO, R. D. B. Otimizando os processos logísticos pela implantação do otif com lean seis sigma. Tecnologia em Metalurgia, Materiais e Mineração, v. 5, n. 4, p. 235, 2009. ISSN 2176-1515.

PEDROSO, M. A. A. M. et al. Diagnóstico do planejamento, programação e controle da produção em uma empresa manufatureira do setor de biotecnologia. Revista Produção Industrial e Serviços, v. 3, n. 2, p. 01-13, 2016.

PEREIRA, S. R. et al. Informática em Logística: sistema WMS para gestão de armazéns. FaSCi-Tech, v. 1, n. 3, 2016. ISSN 2176-9427.

RAMOS, A. L.; CÂNDIDO, G. J.; ESTENDER, A. C. A importância do planejamento e controle de produção. Aten@-Revista Digital de Gestão \& Negócios-, v. 2, n. 3, p. 40-54, 2019.

RAMOS, A. S. M.; OLIVEIRA, M. A. D. Fatores de sucesso na implementação de sistemas integrados de gestão empresarial (ERP): estudo de caso em uma média empresa. XXII Encontro Nacional de Engenharia de Produção Curitiba, 2002.

RIGOleto, Â. A.; PEREIRA, E. M.; DURAN, J. E. A gestão de estoque como ferramenta estratégica na redução de custos. Revista Eletrônica Organizações e Sociedade, v. 6, n. 6, p. 103-114, 2017.

RODRIGUES, E. F. et al. Logística integrada aplicada a um centro de distribuição: comparativo do desempenho do processo de armazenagem após a implementação de um sistema de gerenciamento de armazém (WMS). VII Simpósio de Excelência em Gestão e Tecnologia-SEGeT. Resende-RJ, 2010.

RODRIGUES, M. D.; INÁCIO, R. D. O. Planejamento e controle da produção: um estudo de caso em uma empresa metalúrgica. Revista de Inovação, Gestão e Produção. Santa Maria, RS, v. 2, n. 11, p. 72-80, 2010.

SAWY, Omar A. El. Redesigning enterprise processes for e-business. McGrawHill, Inc., 2001.

SLACK, N.; CHAMBERS, S.; JOHNSTON, R. Administração da produção. São Paulo: Atlas, 2009. 
SILVA, A. A. A. D.; SILVA, J. A. D. A utilização do indicador OTIF como ferramenta para a satisfação do cliente: um estudo em uma empresa da indústria cimenteira. 2019. 67 f. Monografia (Graduação) - Universidade Federal Rural da Amazônia, Capanema, 2019.

STONEHOUSE, G; SNOWDON, B. Competitive advantage revisited: Michael Porter on strategy and competitiveness. Journal of Management Inquiry, v. 16, n. 3, p. 256273, 2007.

TUBINO, D. F. Planejamento e controle da produção: teoria e prática. São Paulo: Atlas, 2009.

UEDA, R. M. Análise das atividades de planejamento e controle da produção (PCP) em uma indústria de nutrição animal. 2016. 64 f. Monografia (Graduação) Universidade Federal da Grande Dourados - Faculdade de Engenharia, Dourados, 2016.

VIANA, J. J. Administração de materiais: um enfoque prático. São Paulo: Atlas, 2000 YIN, R. K. Estudo de caso: planejamento e métodos. 2a edição. Porto Alegre, 2001. 